Prepared in cooperation with the Chester County Water Resources Authority and the Chester County Health Department

\title{
Estimated Suspended-Sediment Loads and Yields in the French and Brandywine Creek Basins, Chester County, Pennsylvania, Water Years 2008-09
}

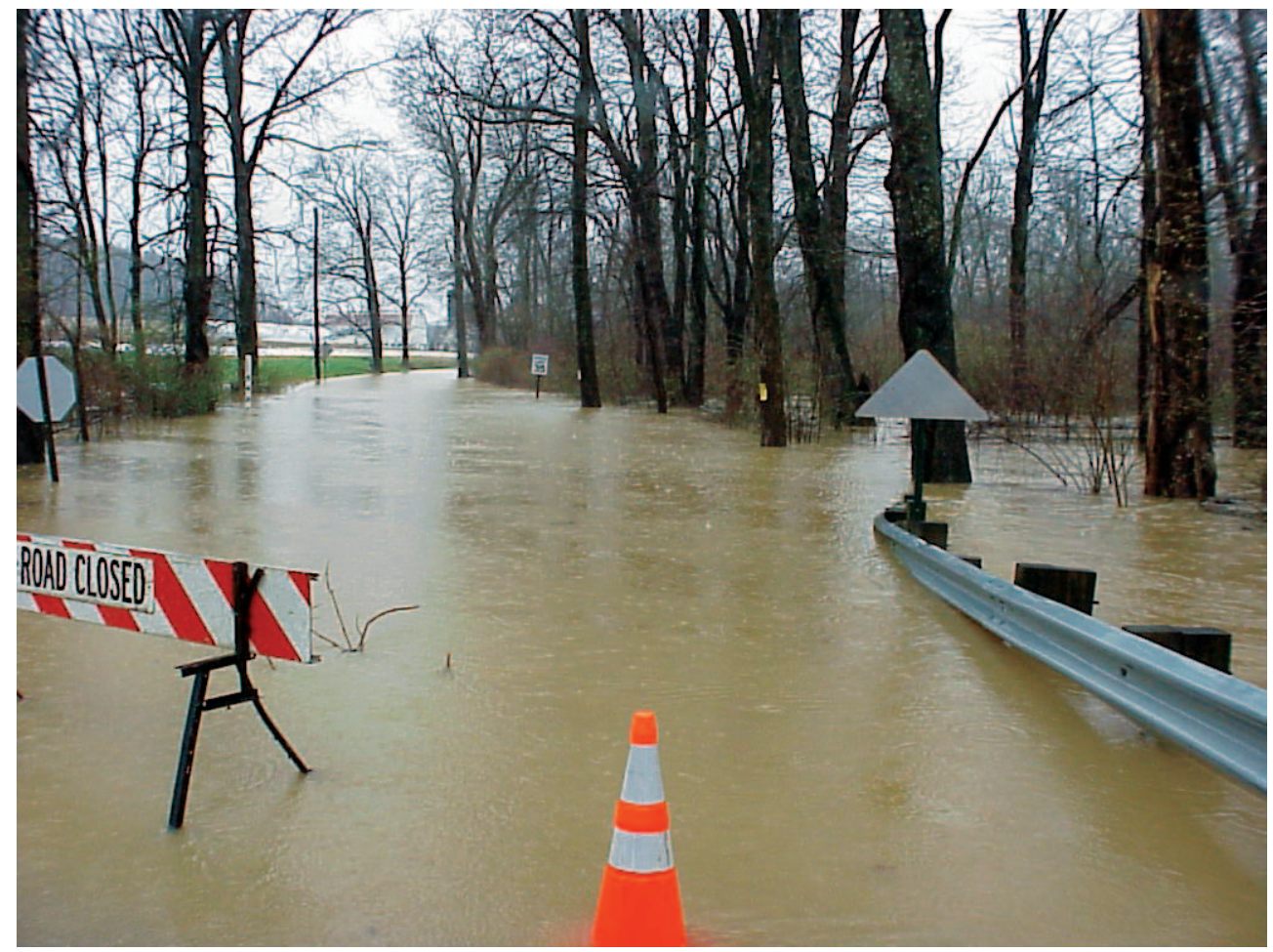

Scientific Investigations Report 2011-5109 
Cover. West Branch Brandywine Creek near Honey Brook, Pennsylvania, overflowing its banks on April 15, 2007. The streamgage and water-quality monitoring station is to the right of the photograph. 


\section{Estimated Suspended-Sediment Loads and Yields in the French and Brandywine Creek Basins, Chester County, Pennsylvania, Water Years 2008-09}

By Ronald A. Sloto and Leif E. Olson

Prepared in cooperation with the Chester County Water Resources Authority and the Chester County Health Department

Scientific Investigations Report 2011-5109 


\title{
U.S. Department of the Interior \\ KEN SALAZAR, Secretary \\ U.S. Geological Survey \\ Marcia K. McNutt, Director
}

\author{
U.S. Geological Survey, Reston, Virginia: 2011
}

For more information on the USGS - the Federal source for science about the Earth, its natural and living resources, natural hazards, and the environment, visit http://www.usgs.gov or call 1-888-ASK-USGS.

For an overview of USGS information products, including maps, imagery, and publications, visit http://www.usgs.gov/pubprod

To order this and other USGS information products, visit http://store.usgs.gov

Any use of trade, product, or firm names is for descriptive purposes only and does not imply endorsement by the U.S. Government.

Although this report is in the public domain, permission must be secured from the individual copyright owners to reproduce any copyrighted materials contained within this report.

Suggested citation:

Sloto, R.A., and Olson, L.E., Estimated suspended-sediment loads and yields in the French and Brandywine Creek Basins, Chester County, Pennsylvania, water years 2008-09: U.S. Geological Survey Scientific Investigations Report 2011-5109, 31 p. 


\section{Contents}

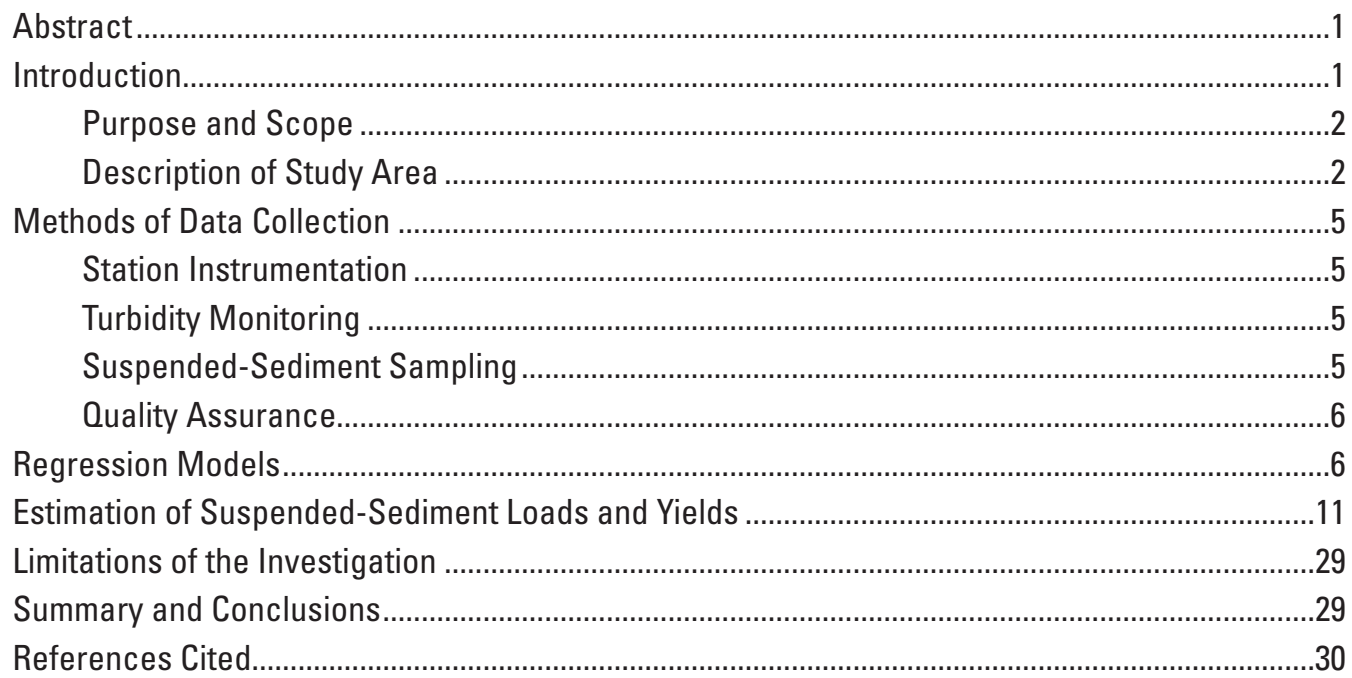

\section{Figures}

1. Map showing water-quality-monitoring stations on French and Brandywine Creeks,

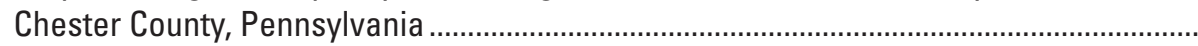

2. Photograph showing turbidity sensor deployed at East Branch Brandywine Creek below Downingtown, Pennsylvania ...................................................................................5

3. Graph showing regression relations of turbidity and suspended-sediment concentration for French Creek near Phoenixville, Pennsylvania .....................................8

4. Graph showing regression relations of turbidity to suspended-sediment concentration for West Branch Brandywine Creek near Honey Brook, Pennsylvania ...

5. Graph showing regression relations of turbidity to suspended-sediment concentration for West Branch Brandywine Creek at Modena, Pennsylvania.................9

6. Graph showing regression relations of turbidity to suspended-sediment concentration for East Branch Brandywine Creek below Downingtown, Pennsylvania .

7. Graph showing discharge and turbidity measured at West Branch Brandywine Creek near Honey Brook, Pennsylvania, December 16-26, 2008

8. Graph showing discharge and turbidity measured at French Creek near Phoenixville, Pennsylvania, August 2-16, 2009

9. Graphs showing suspended-sediment loads for storms at French Creek near Phoenixville, Pennsylvania, 2008 and 2009 water years

10. Graphs showing relation of storm suspended-sediment load to peak discharge at French Creek near Phoenixville, Pennsylvania, 2008 and 2009 water years.

11. Graphs showing suspended-sediment loads for storms at West Branch Brandywine Creek near Honey Brook, Pennsylvania, 2008 and 2009 water years 
12. Graph showing relation of storm suspended-sediment load to peak discharge at West Branch Brandywine Creek near Honey Brook, Pennsylvania, 2008 and 2009 water years

13. Graphs showing suspended-sediment loads for storms at West Branch Brandywine Creek at Modena, Pennsylvania, 2008 and 2009 water years

14. Graph showing relation of storm suspended-sediment load to peak discharge at West Branch Brandywine Creek at Modena, Pennsylvania, 2008 and 2009 water years.

15. Graphs showing suspended-sediment loads for storms at East Branch Brandywine Creek below Downingtown, Pennsylvania, 2008 and 2009 water years.

16. Graph showing relation of storm suspended-sediment load to peak discharge at East Branch Brandywine Creek below Downingtown, Pennsylvania, 2008 and 2009 water years

\section{Tables}

1. Water-quality monitoring stations on French and Brandywine Creeks, Chester County, Pennsylvania

2. Basin characteristics, French and Brandywine Creeks, Chester County, Pennsylvania

3. Regression models developed for French and Brandywine Creeks, Chester County, Pennsylvania, with suspended sediment concentration as the response variable.........7

4. Estimated annual suspended-sediment loads and yields for French and Brandywine Creeks, Chester County, Pennsylvania, 2008 and 2009 water years

5. Daily sediment load for French Creek near Phoenixville, Pennsylvania, 2008 water year

6. Daily sediment load for French Creek near Phoenixville, Pennsylvania, 2009 water year

7. Daily sediment load for West Branch Brandywine Creek near Honey Brook, Pennsylvania, 2008 water year.

8. Daily sediment load for West Branch Brandywine Creek near Honey Brook, Pennsylvania, 2009 water year.

9. Daily sediment load for West Branch Brandywine Creek at Modena,

Pennsylvania, 2008 water year...

10. Daily sediment load for West Branch Brandywine Creek at Modena, Pennsylvania, 2009 water year.

11. Daily sediment load for East Branch Brandywine Creek below Downingtown, Pennsylvania, 2008 water year.

12. Daily sediment load for East Branch Brandywine Creek below Downingtown, Pennsylvania, 2009 water year. 


\section{Conversion Factors and Abbreviations}

\begin{tabular}{lll}
\hline \multicolumn{1}{c}{ Multiply } & By & \multicolumn{1}{c}{ To obtain } \\
\hline inch (in) & Length & \\
foot (ft) & 2.54 & centimeter $(\mathrm{cm})$ \\
mile (mi) & 0.3048 & meter $(\mathrm{m})$ \\
mile per square mile $\left(\mathrm{mi}^{\prime} / \mathrm{mi}^{2}\right)$ & 1.609 & kilometer $(\mathrm{km})$ \\
& 4.167 & kilometer per square kilometer \\
& & \\
\hline & Area $\left./ \mathrm{km}^{2}\right)$ \\
\hline square mile $\left(\mathrm{mi}^{2}\right)$ & 2.590 & square $\mathrm{kilometer}\left(\mathrm{km}^{2}\right)$ \\
\hline & Flow rate & \\
\hline cubic foot per second $\left(\mathrm{ft}^{3} / \mathrm{s}\right)$ & 0.02832 & cubic meter per second $\left(\mathrm{m}^{3} / \mathrm{s}\right)$ \\
\hline & Mass & \\
\hline pound, avoirdupois $(\mathrm{lb})$ & 0.4536 & kilogram $(\mathrm{kg})$ \\
ton, short $(2,000 \mathrm{lb})$ & 0.9072 & megagram $(\mathrm{Mg})$ \\
ton per stream mile (ton $\left./ \mathrm{mi}^{2}\right)$ & 1.46 & megagram per stream $\mathrm{kilometer}$ \\
& & $(\mathrm{Mg} / \mathrm{km})$ \\
ton per square mile (ton $\left./ \mathrm{mi}^{2}\right)$ & 2.35 & megagram per square $\mathrm{kilometer}$ \\
& & $\left(\mathrm{Mg} / \mathrm{km}{ }^{2}\right)$ \\
ton per year (ton $/ \mathrm{yr})$ & 0.9072 & megagram per year $(\mathrm{Mg} / \mathrm{yr})$ \\
\hline
\end{tabular}

FNU Formazine nephelometric unit

Q Discharge

SSC Suspended-sediment concentration

SSL Suspended-sediment load

SSY Suspended-sediment yield

T Turbidity 
(This page intentionally left blank.) 


\title{
Estimated Suspended-Sediment Loads and Yields in the French and Brandywine Creek Basins, Chester County, Pennsylvania, Water Years 2008-09
}

\author{
By Ronald A. Sloto and Leif E. Olson
}

\section{Abstract}

Turbidity and suspended-sediment concentration data were collected by the U.S. Geological Survey (USGS) at four stream stations - French Creek near Phoenixville, West Branch Brandywine Creek near Honey Brook, West Branch Brandywine Creek at Modena, and East Branch Brandywine Creek below Downingtown - in Chester County, Pa. Sedimentation and siltation is the leading cause of stream impairment in Chester County, and these data are critical for quantifying sediment transport. This study was conducted by the USGS in cooperation with the Chester County Water Resources Authority and the Chester County Health Department.

Data from optical turbidity sensors deployed at the four stations were recorded at 15 - or 30-minute intervals by a data logger and uploaded every 1 to 4 hours to the USGS database. Most of the suspended-sediment samples were collected using automated samplers. The use of optical sensors to continuously monitor turbidity provided an accurate estimate of sediment fluctuations without the collection and analysis costs associated with intensive sampling during storms. Turbidity was used as a surrogate for suspended-sediment concentration (SSC), which is a measure of sedimentation and siltation. Regression models were developed between SSC and turbidity for each of the monitoring stations using SSC data collected from the automated samplers and turbidity data collected at each station. Instantaneous suspended-sediment loads (SSL) were computed from time-series turbidity and discharge data for the 2008 and 2009 water years ${ }^{1}$ using the regression equations. The instantaneous computations of SSL were summed to provide daily, storm, and water year annual loads. The annual SSL contributed from each basin was divided by the upstream drainage area to estimate the annual sediment yield.

For all four basins, storms provided more than 96 percent of the annual SSL. In each basin, four storms generally

\footnotetext{
${ }^{1} \mathrm{~A}$ water year is the 12-month period from October 1 to September 30. It is designated by the year in which it ends.
}

provided over half the annual SSL each water year. Stormflows with the highest peak discharges generally carried the highest SSLs. For all stations, the greatest SSLs occurred during the late winter in February and March during the 2008 water year. During the 2009 water year, the greatest SSLs occurred during December and August.

For French Creek near Phoenixville, the estimated annual SSL was 3,500 tons, and the estimated yield was 59.1 tons per square mile (ton $/ \mathrm{mi}^{2}$ ) for the 2008 water year. For the 2009 water year, the annual SSL was 4,390 tons, and the yield was 74.3 ton $/ \mathrm{mi}^{2}$. For West Branch Brandywine Creek near Honey Brook, the estimated annual SSL was 4,580 tons, and the estimated yield was $245 \mathrm{ton} / \mathrm{mi}^{2}$ for the 2008 water year. For the 2009 water year, the annual SSL was 2,300 tons, and the yield was 123 ton $/ \mathrm{mi}^{2}$. For West Branch Brandywine Creek at Modena, the estimated annual SSL was 7,480 tons, and the estimated yield was 136 ton $/ \mathrm{mi}^{2}$ for the 2008 water year. For the 2009 water year, the annual SSL was 4,930 tons, and the yield was 90 ton $/ \mathrm{mi}^{2}$. For East Branch Brandywine Creek below Downingtown, the estimated annual SSL was 8,900 tons, and the estimated yield was 100 ton $/ \mathrm{mi}^{2}$ for the 2008 water year. For the 2009 water year, the annual SSL was 7,590 tons, and the yield was 84 ton $/ \mathrm{mi}^{2}$.

\section{Introduction}

Sedimentation and siltation is the leading cause of stream impairment in Pennsylvania. The Pennsylvania Department of Environmental Protection state-wide water-quality assessment summary lists siltation as the major cause of impairment for 8,271 miles of streams in Pennsylvania (Pennsylvania Department of Environmental Protection, 2010, p. 40). In Chester County, 16.5 stream miles (33.8 percent) upstream from West Branch Brandywine Creek near Honey Brook are impaired by siltation (D.E. Crocker, Chester County Water Resources Authority, written comm., 2011). Upstream from West Branch Brandywine Creek at Modena, 20.3 stream miles 
(13.9 percent) are impaired by siltation. Upstream from East Branch Brandywine Creek below Downingtown, 22 stream miles ( 8.4 percent) are impaired by siltation. The drainage area upstream from French Creek near Phoenixville is not impaired by siltation.

Estimation of sediment loading in a stream typically requires the use of automated event samplers to collect a limited number of samples for laboratory analysis. The discrete samples generally are used in combination with streamdischarge data to estimate sediment concentrations and predict loads. Because of budget limitations and the labor intensive nature of sediment sampling, sediment loads are often based on a small number of samples. The use of optical sensors to continuously monitor turbidity provides an accurate estimate of sediment fluctuations without the collection and analysis costs associated with intensive sampling during storms.

Turbidity is a principal physical characteristic of water and is an expression of the optical property that causes light to be scattered and absorbed by particles and molecules rather than transmitted in straight lines through a water sample. It is caused by suspended matter or impurities that interfere with the clarity of the water. These impurities may include clay, silt, finely divided inorganic and organic matter, soluble colored organic compounds, and microscopic organisms (U.S. Environmental Protection Agency, 1999, p. 7-1). Suspended solids affect the scattering of light, and turbidity increases as the scattering of light increases.

Turbidity or turbidity and discharge are often better indicators of suspended-sediment concentration (SSC) than the traditional sediment-transport curve method for some streams. Lee and others (2008) compared annual suspended-sediment loads (SSL) computed using traditional sediment-transport curve methods and a turbidity-SSC model at stations near John Redmond Reservoir in Kansas. They found that the SSL calculated from the turbidity-SSC model had an error of 1.1 to 3.2 percent, whereas the SSL calculated from sediment-transport curves had an error of 16 to 20 percent.

Turbidity can serve as a surrogate for SSC. In-stream continuous turbidity and discharge data, calibrated with measured SSC data, can be used to compute a time-series of SSC and SSL at a stream station. Turbidity data were collected by the U.S. Geological Survey (USGS) at four stream stations in Chester County, Pa., in cooperation with the Chester County Water Resources Authority and the Chester County Health Department, with the intent to develop time-series SSC and SSL estimates. Data collection began in April 2007 and is continuing (2011).

\section{Purpose and Scope}

This report presents the relations between turbidity and SSC at four stream stations in Chester County, Pa.-French Creek near Phoenixville, West Branch Brandywine Creek near Honey Brook, West Branch Brandywine Creek at Modena, and East Branch Brandywine Creek below Downingtown. Regression models were developed to use turbidity and discharge data to compute time-series SSC at the four stations for the 2008 and 2009 water years. Estimated daily, storm, and annual loads and estimated annual yields are presented for each station.

\section{Description of Study Area}

The study area encompasses four subbasins in Chester County, Pa. (fig. 1, table 1). Chester County is a $760-\mathrm{mi}^{2}$ area in southeastern Pennsylvania. The county lies in the Piedmont Physiographic Province. This area is characterized by rolling hills underlain by sedimentary rock and deeply weathered crystalline rock. The largest stream in Chester County is Brandywine Creek, which drains $290 \mathrm{mi}^{2}$ (38 percent) of the county. Three of the study subbasins are in the Brandywine Creek Basin. Brandywine Creek is a tributary to the Christina River, which drains to the Delaware River. The fourth station is in the $70.7-\mathrm{mi}^{2}$ French Creek Basin. French Creek is a tributary to the Schuylkill River, which is a major tributary to the Delaware River.

Chester County is undergoing rapid urbanization. Suburban development is concentrated in the eastern and central parts of the county. The northern and western parts of the county are rural with more farm land and pasture than the eastern and central parts. Major crops are hay and corn. Dairy and equestrian farms are also common. The East Branch Brandywine Creek near Honey Brook subbasin has the most agricultural and pasture land (59.7 percent), whereas the West Branch Brandywine Creek subbasin between the Honey Brook and Modena water-quality monitoring stations has the least (26.4 percent) (table 2). The French Creek subbasin has the most forest land (44.6 percent), whereas the East Branch Brandywine Creek near Honey Brook subbasin has the least (17.6 percent). The West Branch Brandywine Creek subbasin between the Honey Brook and Modena stations and East Branch Brandywine Creek below Downingtown subbasins are the most urbanized (31.5 and 31.9 percent urban land, respectively). 


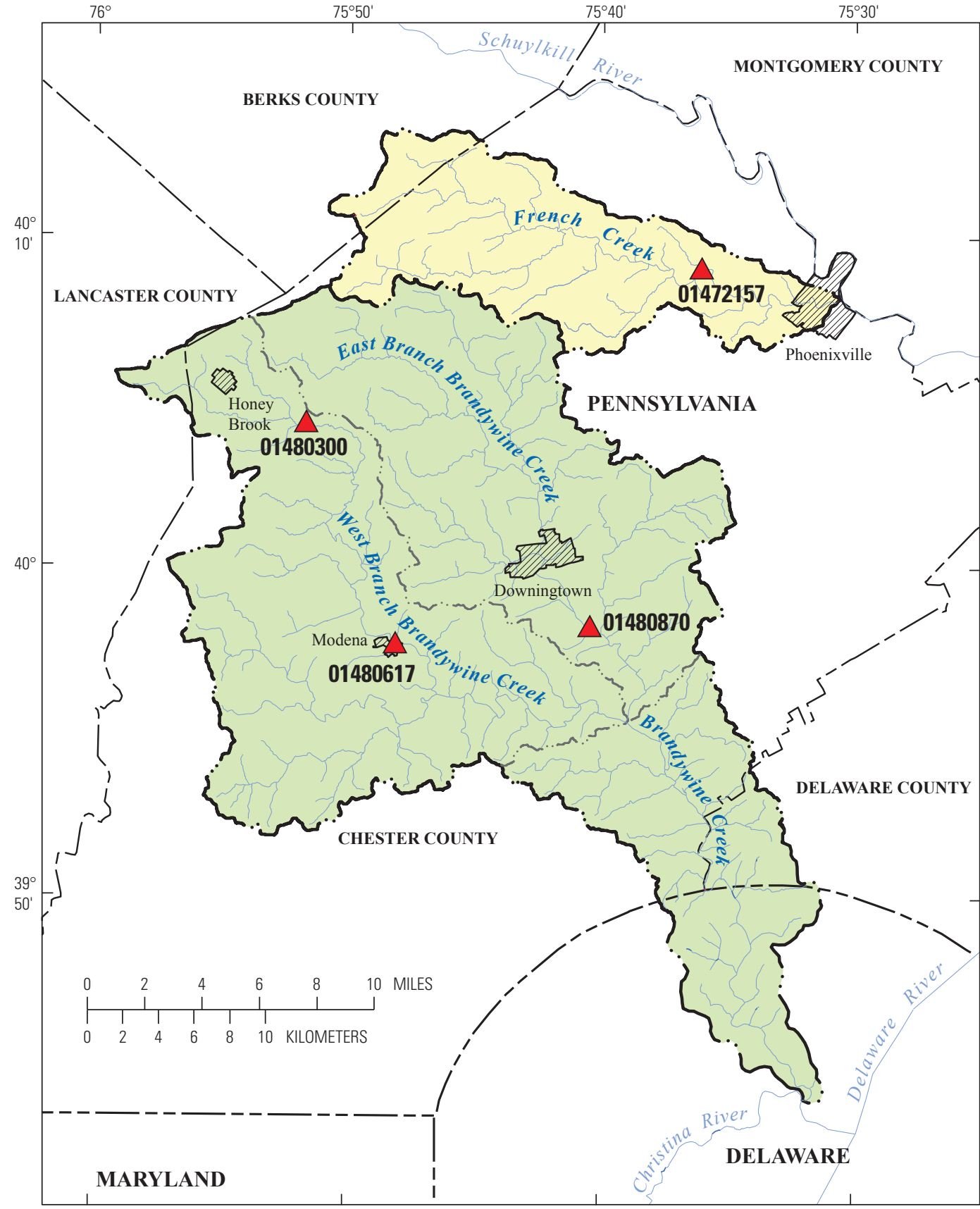

Base from U.S. Geological Survey digital data, 1972,1:2,000,000 Albers Equal-Area Conic Projection.Standard parallels $29^{\circ} 30^{\prime} \mathrm{N}$, central meridian $75^{\circ} 00^{\prime} \mathrm{W}$.

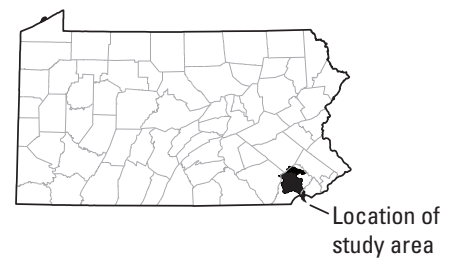

EXPLANATION

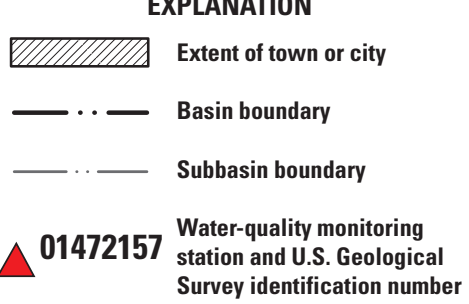

Figure 1. Water-quality-monitoring stations on French and Brandywine Creeks, Chester County, Pennsylvania. 
Table 1. Water-quality monitoring stations on French and Brandywine Creeks, Chester County, Pennsylvania.

$\left[\mathrm{mi}^{2}\right.$, square miles]

\begin{tabular}{|c|c|c|c|c|c|}
\hline $\begin{array}{c}\text { U.S. Geological Survey } \\
\text { station-identification } \\
\text { number }\end{array}$ & Water-quality monitoring station & Latitude & Longitude & $\begin{array}{l}\text { Drainage } \\
\text { area } \\
\left(\mathrm{mi}^{2}\right)\end{array}$ & $\begin{array}{l}\text { Measured water-quality } \\
\text { characteristics }\end{array}$ \\
\hline 01472157 & French Creek near Phoenixville, Pa. & $40^{\circ} 09^{\prime} 05^{\prime \prime}$ & $75^{\circ} 36^{\prime} 06^{\prime \prime}$ & 59.1 & Turbidity \\
\hline 01480300 & $\begin{array}{l}\text { West Branch Brandywine Creek } \\
\text { near Honey Brook, Pa. }\end{array}$ & $40^{\circ} 04^{\prime} 22^{\prime \prime}$ & $75^{\circ} 51^{\prime} 40^{\prime \prime}$ & 18.7 & Turbidity \\
\hline 01480617 & $\begin{array}{l}\text { West Branch Brandywine Creek at } \\
\text { Modena, Pa. }\end{array}$ & $39^{\circ} 57^{\prime} 42^{\prime \prime}$ & $75^{\circ} 48^{\prime} 06^{\prime \prime}$ & 55 & $\begin{array}{l}\text { Turbidity, } \mathrm{pH} \text {, dissolved oxygen, } \\
\text { conductivity, temperature }\end{array}$ \\
\hline 01480870 & $\begin{array}{l}\text { East Branch Brandywine Creek } \\
\text { below Downingtown, Pa. }\end{array}$ & $39^{\circ} 58^{\prime} 07^{\prime \prime}$ & $75^{\circ} 40^{\prime} 25^{\prime \prime}$ & 89.9 & $\begin{array}{l}\text { Turbidity, } \mathrm{pH} \text {, dissolved oxygen, } \\
\text { conductivity, temperature }\end{array}$ \\
\hline
\end{tabular}

Table 2. Basin characteristics, French and Brandywine Creeks, Chester County, Pennsylvania.

[Data provided by D.E. Crocker (Chester County Water Resources Authority, written comm., 2011) from 2005 land-use data.]

\begin{tabular}{|c|c|c|c|c|c|}
\hline & $\begin{array}{l}\text { French Creek near } \\
\text { Phoenixville }\end{array}$ & $\begin{array}{c}\text { West Branch } \\
\text { Brandywine Creek } \\
\text { near Honey Brook }\end{array}$ & $\begin{array}{l}\text { West Branch } \\
\text { Brandywine Creek } \\
\text { at Modena }\end{array}$ & $\begin{array}{c}\text { Area between West } \\
\text { Branch Brandywine } \\
\text { Creek near Honey } \\
\text { Brook and Modena }\end{array}$ & $\begin{array}{c}\text { East Branch } \\
\text { Brandywine Creek } \\
\text { below Downingtown }\end{array}$ \\
\hline $\begin{array}{l}\text { Drainage area (square } \\
\text { miles) }\end{array}$ & 59.1 & 18.7 & 55 & 36.3 & 89.9 \\
\hline $\begin{array}{l}\text { Percent of area covered by } \\
\text { forest }\end{array}$ & 44.6 & 17.6 & 27.0 & 31.7 & 27.7 \\
\hline $\begin{array}{l}\text { Percent of area covered by } \\
\text { agriculture and pasture }\end{array}$ & 33.0 & 59.7 & 37.4 & 26.4 & 29.8 \\
\hline $\begin{array}{l}\text { Percent of area covered by } \\
\text { urbanization }\end{array}$ & 16.1 & 13.8 & 25.6 & 31.5 & 31.9 \\
\hline $\begin{array}{l}\text { Percent of area covered by } \\
\text { lakes, ponds, reservoirs, } \\
\text { and wetlands }\end{array}$ & 3.6 & 3.9 & 3.0 & 2.6 & 4.5 \\
\hline Total stream length (miles) & 174.6 & 49 & 146.2 & 97.2 & 261 \\
\hline $\begin{array}{l}\text { Stream density (stream } \\
\text { miles per square mile) }\end{array}$ & 2.95 & 2.62 & 2.66 & 2.68 & 2.90 \\
\hline
\end{tabular}




\section{Methods of Data Collection}

Four water-quality-monitoring stations equipped with turbidity sensors were in operation in the French and Brandywine Creek Basins during water years 2008 and 2009 (table 1). Discharge data were collected at all stations. Published data for these stations are available at http://pa.water.usgs.gov/.

Turbidity data were collected in accordance with the maintenance and calibration protocols described by Wagner and others (2006). Most turbidity data were collected using Yellow Spring Instrument (YSI) Optical Monitoring System (OMS) 600 series and YSI 6920V2 sondes. Analite NEP395G turbidity sensors were installed at the West Branch Brandywine Creek at Modena and East Branch Brandywine Creek below Downingtown stations prior to the study; however, they were replaced with YSI sensors. All turbidity sensors had wipers to reduce biofouling and clean the probe prior to all measurements.

The Analite sensor has a range of 0 to 1,000 Formazine Nephelometric Units (FNU) with an accuracy of \pm 0.2 FNU at 1,000 FNU. A YSI 6136 turbidity sensor was used in both types of YSI sondes. The YSI sensor has a range of 0 to 1,000 FNU with an accuracy of \pm 2 percent of measurement or $0.3 \mathrm{FNU}$, whichever is greater. Both brands of turbidity sensors use near-infrared wavelengths with a single 90-degree detector.

\section{Station Instrumentation}

YSI 6136 turbidity sensors were installed on November 7, 2006, at French Creek near Phoenixville and West Branch Brandywine Creek near Honey Brook. An Analite NEP395 turbidity sensor was installed on September 22, 2005, at West Branch Brandywine Creek at Modena. It was replaced with a YSI 6136 turbidity sensor on February 28, 2007. An Analite NEP395 turbidity sensor was installed on September 26, 2005, at East Branch Brandywine Creek below Downingtown. It was replaced with a YSI 6136 turbidity sensor on August 7, 2008. Turbidity sensors were installed inside 4-in. diameter polyvinyl chloride housings (fig. 2) drilled with circulation holes.

\section{Turbidity Monitoring}

The Analite sensors recorded turbidity data in whole numbers, and the YSI sensors recorded data to 0.1 FNU. All turbidity measurements were recorded at 15- or 30-minute intervals by a data logger and uploaded every 1 to 4 hours to the USGS database. Data from the in-situ sensors were compared with annual cross-sectional data using the technique described in Wagner and others (2006) to verify that the in-situ sensors were installed in representative locations in the stream. No bias was noted for any of the stations.

In order to calculate SSC from turbidity, a complete record of turbidity and discharge is needed. Missing data occurred because of spikes, servicing of the sensor, or fouling.

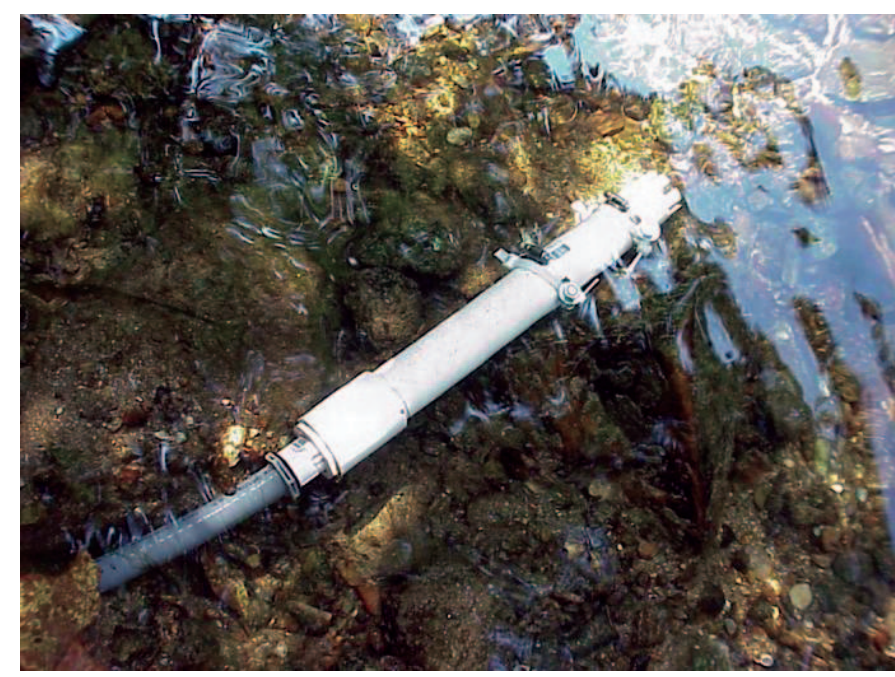

Figure 2. Turbidity sensor deployed at East Branch Brandywine Creek below Downingtown, Pennsylvania. The sensor is installed in a perforated 4-inch-diameter polyvinyl chloride housing for protection.

If field meter values were available, they were used to replace missing data. When the period of time between missing values was small, interpolation between measured data points was used to estimate missing values. Where there were large gaps in the record, data from nearby turbidity sensors and discharge and rainfall data were used to estimate missing values. Missing turbidity values were estimated for the purpose of estimating SSC but were not published or stored in the database.

\section{Suspended-Sediment Sampling}

Most of the suspended-sediment samples were collected using automated samplers. Several grab samples were collected at stations prior to the installation of an automated sampler at that station, and attempts were made to collect equal width integrated (EWI) samples as described by Wilde and others (1999) at all stations concurrently with automated samples to determine mixing. Eighteen EWI samples were collected-1 at French Creek near Phoenixville, 8 at West Branch Brandywine Creek near Honey Brook, 5 at West Branch Brandywine Creek at Modena, and 4 at East Branch Brandywine Creek below Downingtown.

Automated samplers were installed on July 23, 2007, at French Creek near Phoenixville; on April 11, 2007, at West Branch Brandywine Creek near Honey Brook; and on November 15, 2007, at East Branch Brandywine Creek below Downingtown and West Branch Brandywine Creek at Modena. Some of the automated samplers had programmable thresholds for turbidity and discharge to control sample collection. The thresholds were constantly adjusted to better target conditions under which the samples were collected. At other stations, older automated samplers had to be turned on before each storm event; they collected one sample per hour for 24 hours. 
As more funding became available, the older automated samplers were replaced with programmable samplers at all stations, except the West Branch Brandywine Creek near Honey Brook station.

Of the 24 samples collected for a storm, 1 to 6 samples were selected for laboratory analysis. These selections were made to minimize potential bias from serial correlation and reduce the effect of any one event on the overall relation between turbidity and SSC. Serial correlation (also called autocorrelation) occurs when data are collected close enough in time that the regression assumption of data independence is violated. Serial correlation caused by using too many samples from a single storm can cause underestimation of the regression uncertainty. Samples were analyzed at the USGS Kentucky Water Science Center Sediment Laboratory and the USGS Pennsylvania Water Science Center.

\section{Quality Assurance}

Turbidity was measured across the width of the stream during the collection of samples and during annual reviews of in-stream continuous water-quality installations. The same model YSI sonde and turbidity probe were used to collect the cross-section measurements as was deployed at the station. The measurements were made directly across the stream from the in-stream sensors; however, when flows were too high to wade the stream, the cross-sections were measured from the nearest bridge. Cross-sectional turbidity measurements were compared with measurements from in-stream sensors to assess the ability of the in-stream sensors to collect data representative of the width of the stream. Because consistent bias was not observed in the relation at any monitoring location, values from continuous-water-quality monitors are representative of stream-water quality across the width of the stream cross section. Turbidity records generally were rated good (error of $5-10$ percent), occasionally fair (10-15 percent), and rarely poor (greater than 15 percent) on the basis of guidelines developed by Wagner and others (2006).

\section{Regression Models}

Regression models were developed between SSC and turbidity as a means of estimating time-series SSC using turbidity data. Available data from the 2007, 2008, and 2009 water years were used. The estimated SSC was used to compute daily, storm, and annual SSLs at each station for water years 2008 and 2009.

Regression models were developed for the relations of $S S C$ to turbidity $(T)$ and discharge $(Q)$ for each station using SSC data collected by the automated samplers and turbidity and discharge data collected at each station. The methodology was described by Rasmussen and others (2009), Helsel and Hirsch (2002), and Bragg and others (2007). Each station was evaluated independently, and regression equations were developed for each station using model building approaches explained by Helsel and Hirsch (2002).

Six regression models were initially developed for each station: (1) $S S C$ in relation to $T$, (2) $S S C$ to $Q$, (3) $S S C$ to $T$ and $Q$, (4) $\log _{10} S S C$ to $\log _{10} T$, (5) $\log _{10} S S C$ to $\log _{10} Q$, and (6) $\log _{10} S S C$ to $\log _{10} T$ and $\log _{10} Q$. Statistics, including coefficient of determination $\left(R^{2}\right)$, adjusted $R^{2}$, standard error, prediction error sum of squares (PRESS), Mallow's $C p$, variance inflation factor, probability plot correlation coefficient, and model standard percentage error, were used to evaluate the models (table 3). The statistics are appropriate only for comparing models with the same response variable units. The coefficient of determination is the fraction of the variance explained by the regression model. The adjusted coefficient of determination is adjusted for the number of degrees of freedom to allow comparison of regression models with differing numbers of explanatory variables. The standard error is an estimate of the variation from the average. The prediction error sum of squares estimates error by using $n-1$ observations in the regression model to estimate the value left out; a lower PRESS indicates less model error. Mallow's $C p$ is used to assess the fit of a regression model by minimizing bias and standard error; the best model is the one with the lowest $C p$. The variance inflation factor estimates how much the variance of an estimated regression coefficient in a multiple linear regression model is increased because of collinearity. The probability plot correlation coefficient is a test for normal distribution, which will have a correlation coefficient close to 1.0. As data depart from normality, the coefficient drops below 1.0. The model standard percentage error is the root mean squared error expressed as a percentage. It is a measure of the variance between observed values and values computed by the regression model. Uncertainty of regression estimates was determined using 90-percent prediction intervals (Helsel and Hirsch, 1992).

For French Creek near Phoenixville, a linear regression model using turbidity as the explanatory variable provided the best results (table 3). The regression model selected for French Creek was

$$
S S C=1.689 T-3.954
$$

The relation between $S S C$ and $T$ is shown in figure 3. Turbidity explained 96 percent of the variability in SSC values.

For West Branch Brandywine Creek near Honey Brook, the magnitudes of the correlation coefficients among SSC, $T$, and discharge were lower than for the other stations (table 3). A multiple linear regression using $T$ and discharge as the explanatory variables (adjusted $R^{2}=0.75$ ) and a simple linear regression using $T$ as the explanatory variable (adjusted $R^{2}=0.74$ ) gave approximately the same results. Because of the similarity of the coefficients of determination, the simpler model was chosen. The regression model selected for the Honey Brook station was

$$
S S C=1.8729 T-11.5034 .
$$


Table 3. Regression models developed for French and Brandywine Creeks, Chester County, Pennsylvania, with suspended sediment concentration as the response variable.

$\left[\mathrm{R}^{2}\right.$, coefficient of determination; PPCC, probability plot correlation coefficient; PRESS, prediction error sum of squares; MSPE, model standard percentage error; VIF, variance inflation factor; -- statistic not applicable; $n$, number of observations; $T$, turbidity; $Q$, discharge]

\begin{tabular}{|c|c|c|c|c|c|c|c|c|}
\hline $\begin{array}{l}\text { Explanatory } \\
\text { variable }\end{array}$ & $R^{2}$ & Adjusted $R^{2}$ & $\begin{array}{c}\text { Standard } \\
\text { error }\end{array}$ & PPCC & PRESS & $\begin{array}{c}\text { Mallow's } \\
C_{p}\end{array}$ & MSPE & VIF \\
\hline \multicolumn{9}{|c|}{ French Creek near Phoenixville ( $n=106)$} \\
\hline$T$ & 0.957 & 0.956 & 26.0 & 0.995 & 77,858 & 4.64 & 14.7 & -- \\
\hline$Q$ & 0.285 & 0.278 & 99.6 & 0.953 & $1,076,112$ & 1,340 & 57.0 & -- \\
\hline$T, Q$ & 0.949 & 0.948 & 26.8 & 0.985 & 79,437 & 3 & -- & 1.34 \\
\hline $\log _{10} T$ & 0.928 & 0.928 & 0.10 & 0.961 & 1.03 & 1.32 & 22.4 & -- \\
\hline $\log _{10} Q$ & 0.448 & 0.443 & 0.27 & 0.997 & 7.71 & 693 & 65.6 & -- \\
\hline $\log _{10} T$ and $\log _{10} Q$ & 0.929 & 0.927 & 0.10 & 0.960 & 1.04 & 3 & -- & 1.88 \\
\hline \multicolumn{9}{|c|}{ West Branch Brandywine Creek near Honey Brook ( $n=74)$} \\
\hline$T$ & 0.744 & 0.741 & 70.6 & 0.996 & 371,425 & 3.93 & 39.0 & -- \\
\hline$Q$ & 0.087 & 0.074 & 134 & 0.971 & $1,391,323$ & 191 & 73.5 & -- \\
\hline$T, Q$ & 0.757 & 0.750 & 69.6 & 0.996 & 372,461 & 3 & -- & 1.25 \\
\hline $\log _{10} T$ & 0.710 & 0.705 & 0.21 & 0.986 & 3.21 & 1.00 & 49.8 & -- \\
\hline $\log _{10} Q$ & 0.398 & 0.390 & 0.30 & 0.977 & 6.73 & 74.94 & 74.6 & -- \\
\hline $\log _{10} T$ and $\log _{10} Q$ & 0.710 & 0.701 & 0.21 & 0.986 & 3.31 & 3 & -- & 2.27 \\
\hline \multicolumn{9}{|c|}{ West Branch Brandywine Creek at Modena ( $n=79)$} \\
\hline$T$ & 0.936 & 0.935 & 29.9 & 0.985 & 82,901 & 1.13 & 18.20 & -- \\
\hline$Q$ & 0.183 & 0.172 & 107 & 0.849 & 918,636 & 893 & 65.0 & -- \\
\hline$T, Q$ & 0.936 & 0.934 & 30.2 & 0.988 & 87,914 & 3 & -- & 1.26 \\
\hline $\log _{10} T$ & 0.503 & 0.497 & 0.22 & 0.992 & 3.97 & 466 & 53.3 & -- \\
\hline $\log _{10} Q$ & 0.928 & 0.927 & 0.08 & 0.991 & 0.58 & 3.13 & 19.5 & -- \\
\hline $\log _{10} T$ and $\log _{10} Q$ & 0.930 & 0.928 & 0.08 & 0.991 & 0.58 & 3 & -- & 1.98 \\
\hline \multicolumn{9}{|c|}{ East Branch Brandywine Creek below Downingtown ( $n=55$ ) } \\
\hline$T$ & 0.938 & 0.937 & 45.7 & 0.989 & 132,881 & 2.42 & 18.7 & -- \\
\hline$Q$ & 0.029 & 0.011 & 184 & 0.887 & $1,911,963$ & 639 & 75.58 & -- \\
\hline$T, Q$ & 0.927 & 0.924 & 51.1 & 0.969 & 169,811 & 3 & -- & 1.01 \\
\hline $\log _{10} T$ & 0.944 & 0.943 & 0.09 & 0.992 & 0.49 & 8.98 & 21.44 & -- \\
\hline $\log _{10} Q$ & 0.369 & 0.357 & 0.31 & 0.993 & 1.30 & 5.52 & 624 & -- \\
\hline $\log _{10} T$ and $\log _{10} Q$ & 0.951 & 0.950 & 0.09 & 0.989 & 0.44 & 3 & -- & 1.44 \\
\hline
\end{tabular}


The relation between $S S C$ and $T$ is shown in figure 4. Turbidity explained 74 percent of the variability in SSC values.

For West Branch Brandywine Creek at Modena, a multiple linear regression using $T$ and discharge as the explanatory variables (adjusted $\mathrm{R}^{2}=0.93$ for untransformed data and adjusted $R^{2}=0.94$ for logarithmic base-10 transformation data) and a simple linear regression using $T$ as the explanatory variable (adjusted $R^{2}=0.94$ ) gave approximately the same results (table 3 ). Because of the similarity of the coefficients of determination, the simpler model was chosen. The regression model selected for the Modena station was

The relation between $S S C$ and $T$ is shown in figure 5. Turbidity explained 94 percent of the variability in $S S C$ values.

For East Branch Brandywine Creek below Downingtown, a multiple linear regression using $T$ and discharge as the explanatory variables (adjusted $R^{2}=0.95$ for logarithmic base10 transformation data) and a simple linear regression using $T$ as the explanatory variable (adjusted $R^{2}=0.94$ for logarithmic base-10 transformation data) gave approximately the same results (table 3). Because of the similarity of the coefficients of determination, the simpler model was chosen. The regression relation model selected for the Downingtown station was

$$
\log (S S C)=1.0115 \log (T)+0.2596
$$
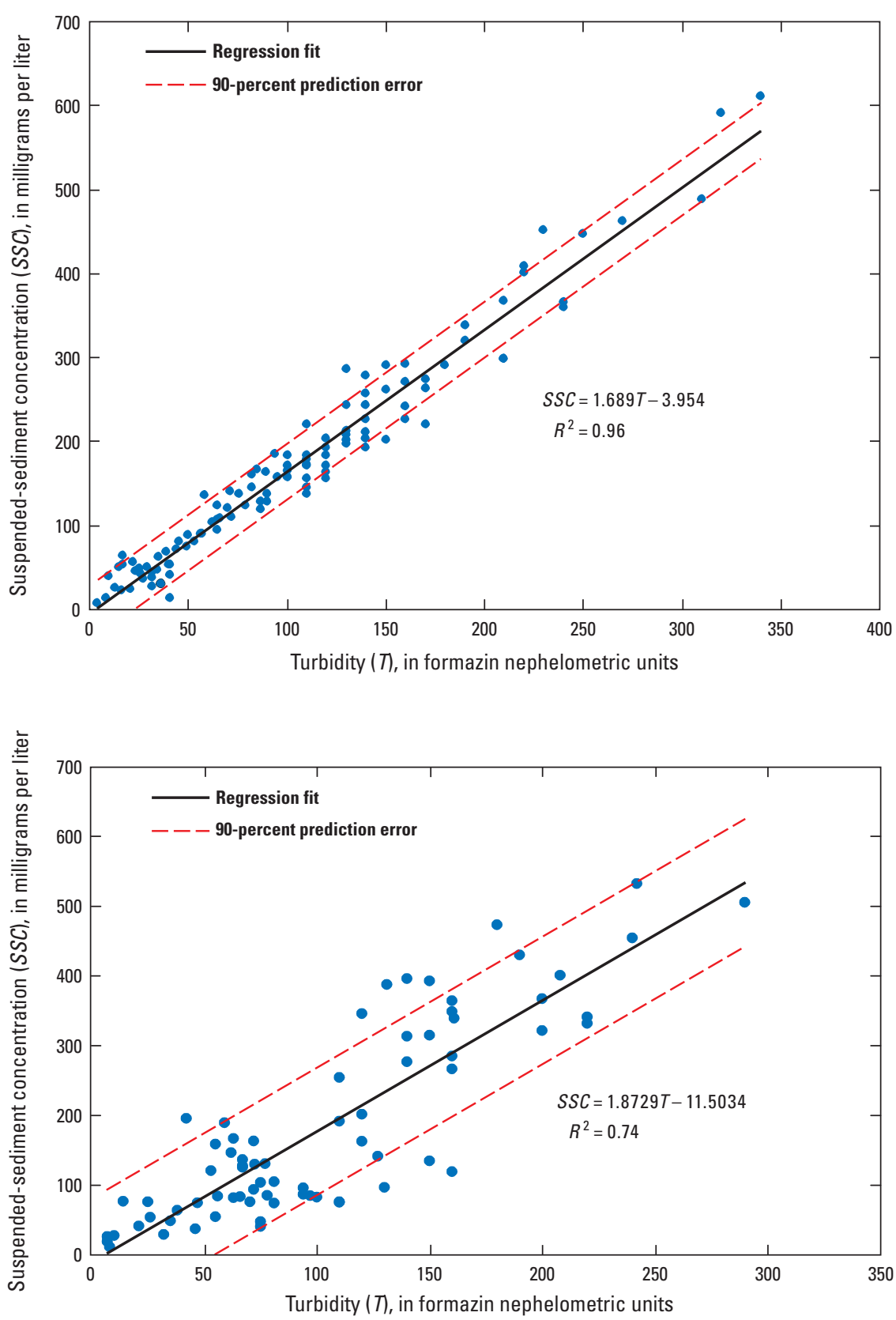

Figure 3. Regression relations of turbidity and suspended-sediment concentration for French Creek near Phoenixville, Pennsylvania.
Figure 4. Regression relations of turbidity to suspended-sediment concentration for West Branch Brandywine Creek near Honey Brook, Pennsylvania. 
The relation between $S S C$ and $T$ is shown in figure 6. Turbidity explained 94 percent of the variability in $S S C$ values. A Duan's bias correction factor (Duan, 1983) of 1.022 was applied to correct for negative bias during retransformation of the response variable.

Discharge correlated poorly with $S S C$. The adjusted $R^{2}$ values were $0.28,0.07,0.17$, and 0.01 for the Phoenixville, Honey Brook, Modena, and Downingtown stations, respectively (table 3), which indicates that discharge is a poor surrogate for SSC. For example, consider three storms measured at West Branch Brandywine Creek near Honey Brook during December 16-26, 2009 (fig. 7). For the storm beginning December 19, the use of discharge as a surrogate for SSC would provide a good approximation of the SSL. However, for the storms beginning December 16 and 24, the use of discharge as a surrogate for $S S C$ would substantially overestimate the SSL. For French Creek near Phoenixville, discharge is a poor surrogate for SSC (fig. 8).
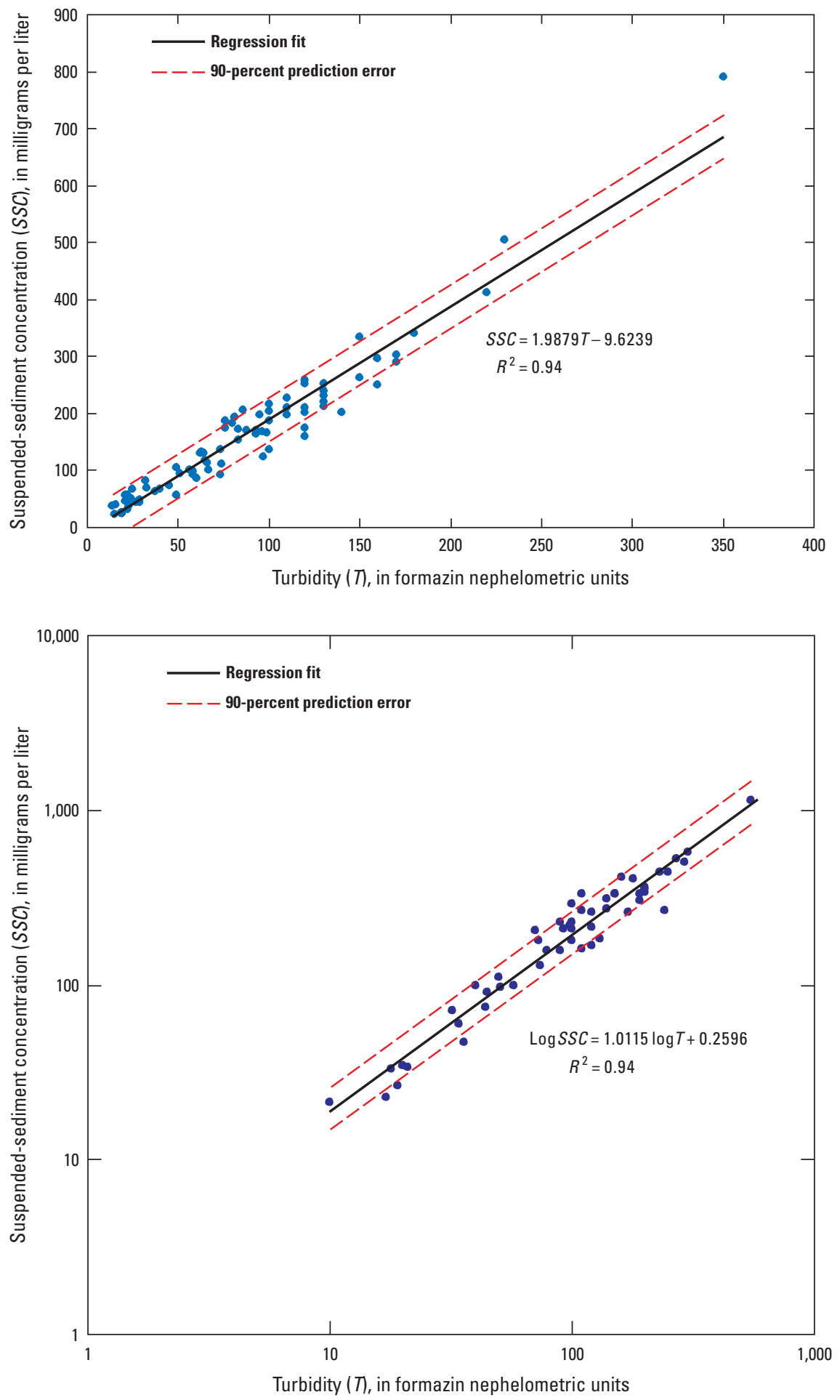

Figure 5. Regression relations of turbidity to suspended-sediment concentration for West Branch Brandywine Creek at Modena, Pennsylvania.
Figure 6. Regression relations of turbidity to suspended-sediment concentration for East Branch Brandywine Creek below Downingtown, Pennsylvania. 

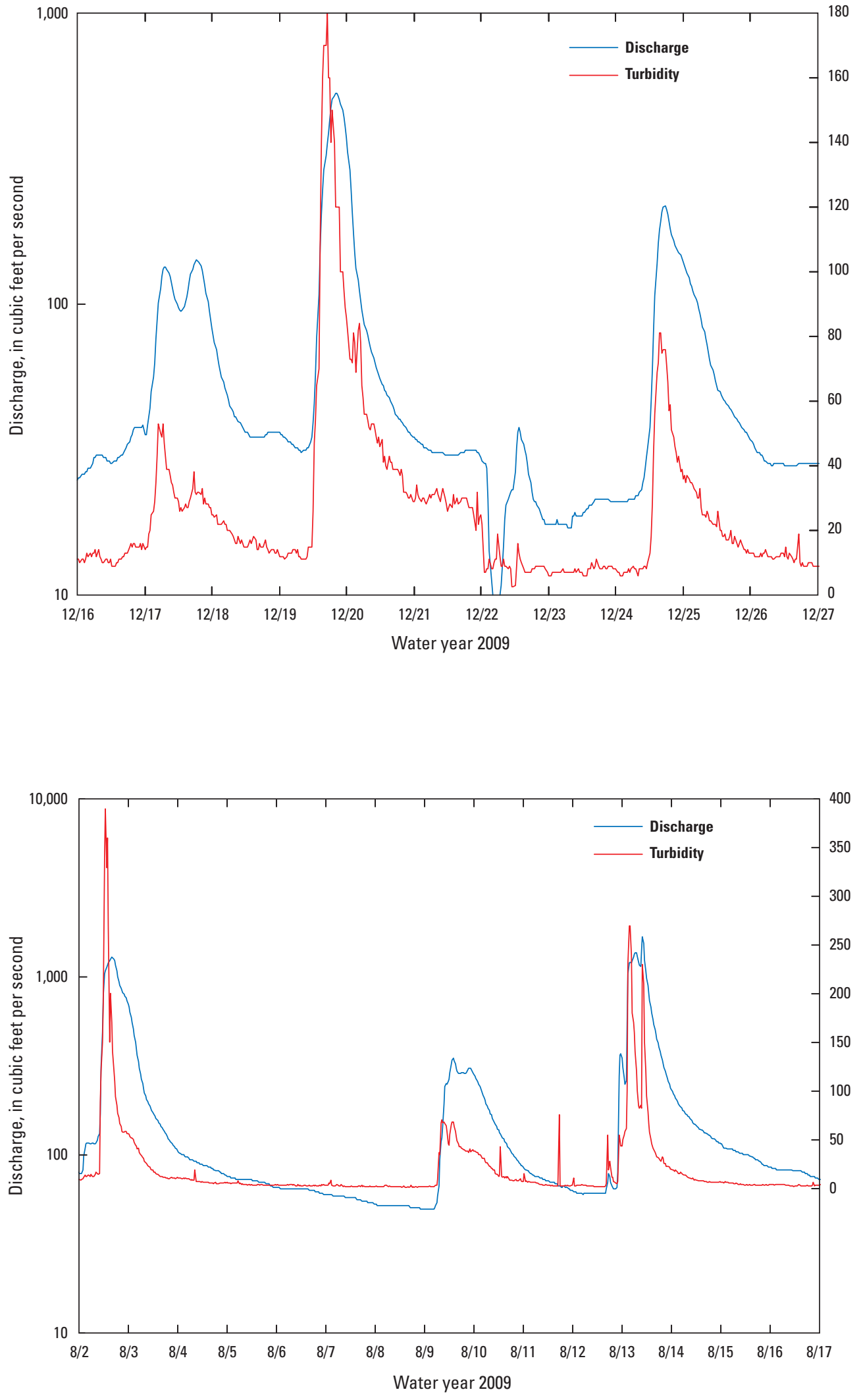

Figure 7. Discharge and turbidity measured at West Branch Brandywine Creek near Honey Brook, Pennsylvania, December 16-26, 2008.
Figure 8. Discharge and turbidity measured at French Creek near Phoenixville, Pennsylvania, August 2-16, 2009. 


\section{Estimation of Suspended-Sediment Loads and Yields}

The term "load" represents the mass (commonly expressed in tons or pounds) of a constituent transported past a sampling station during a specified period of time. Loads can be computed for various time increments, such as instantaneous, daily, monthly, seasonal, annual, or for storms. Instantaneous loads represent the mass transported at the specific sampling time, whereas daily, monthly, seasonal, annual, and storm loads represent the cumulative mass transported over a prolonged period.

Annual loads generally are more informative than instantaneous loads measured at the time of sampling because they represent the cumulative transport of sediment during a year and, thereby, incorporate the potentially large range of daily variations. Annual loads also are useful for evaluating differences in sediment transport among stations to identify source areas contributing substantial inputs. Differences in annual loads transported past sampling stations can result from differences in annual flow volumes, physical basin characteristics, current and historical land-use activities, and localized conditions that affect sediment supply or susceptibility to erosion.

Instantaneous suspended-sediment loads (SSL) were computed from time-series turbidity and discharge data for the 2008 and 2009 water years as follows. Regression equations (1) through (4) were used to compute instantaneous SSC from turbidity data collected every 30 minutes, the common recording time interval for all four stations. SSC values computed from regression estimates were multiplied by the corresponding discharge values and a unit conversion to compute instantaneous estimates of $S S L$ in short tons $(2,000 \mathrm{lbs})$. Instantaneous $S S L$ was calculated using the following equation:

$$
S S L_{i}=S S C_{i} \times Q_{i} \times C,
$$

where

$S S L_{i} \quad$ is the computed suspended-sediment load, in tons per 30-minute interval;

$S_{S C} \quad$ is the computed suspended-sediment concentration for the $i$ th value, in milligrams per liter;

$Q_{i} \quad$ is the discharge for the $i$ th value, in cubic feet per second; and

$C$ is a constant, $5.62 \times 10^{-5}$, for converting the units to tons per 30 minutes.
The instantaneous (30-minute) computations of SSL were summed to provide daily, storm, and annual loads. Estimated annual SSL was determined by summing the estimated 30-minute $S S L$ transported past each of the four sampling stations during water years 2008 and 2009 (table 4). The annual SSL contributed from each subbasin was divided by the upstream drainage area to estimate the annual sediment yield. Annual sediment yields were calculated to compare sediment loads among basins of different sizes and are not meant to imply equal sourcing of sediment throughout the drainage. Annual yields per stream mile also were calculated for each subbasin. However, the stream density in each basin is similar (range of 2.62 to $2.95 \mathrm{mi} / \mathrm{mi}^{2}$, table 2), and the ratios of annual yield per square mile to annual yield per stream mile for all four subbasins ranged from 0.34 to 0.38 .

For French Creek near Phoenixville, the estimated annual $S S L$ was 3,500 tons, and the estimated yields were $59.1 \mathrm{ton} / \mathrm{mi}^{2}$ and 20 tons per stream mile for the 2008 water year (table 4). The storm beginning March 19, 2008, provided 20.4 percent of the annual SSL. The four storms yielding the greatest SSL (storms beginning on March 19, February 13, September 6, and February 1, 2008, in order of load) provided 54 percent of the annual SSL. Storms provided 99.5 percent of the annual $S S L ; 14$ of 41 storms that produced more than 1 ton of sediment provided 90.2 percent of the annual SSL. The highest cumulative SSLs for the 2008 water year occurred during the late winter in February and March (fig. 9, table 5). For the 2009 water year, the estimated annual SSL was 4,390 tons, and the estimated yields were $74.3 \mathrm{ton} / \mathrm{mi}^{2}$ and 25.1 tons per stream mile (table 4 ). The storm beginning December 10, 2008, provided 23.2 percent of the annual SSL. The four storms yielding the greatest $S S L$ (storms beginning on December 10, 2008, and July 27, May 3, and August 2, 2009 , in order of load) provided 56.1 percent of the annual SSL. Storms provided 99.6 percent of the annual SSL; 13 of 43 storms that produced more than 1 ton of sediment provided 90.7 percent of the annual SSL. The highest cumulative SSLs for the 2009 water year occurred during December and the summer in July and August (fig. 9, table 6). Storm flows with the highest peak discharges generally carried the highest SSLs $\left(R^{2}=0.90\right)$ (fig. 10).

For West Branch Brandywine Creek near Honey Brook, the estimated annual SSL was 4,580 tons, and the estimated yields were $245 \mathrm{ton} / \mathrm{mi}^{2}$ and 93.5 tons per stream mile for the 2008 water year (table 4). The storm beginning March 19, 2008, provided 42.4 percent of the annual SSL. The four storms yielding the greatest SSL (storms beginning on 


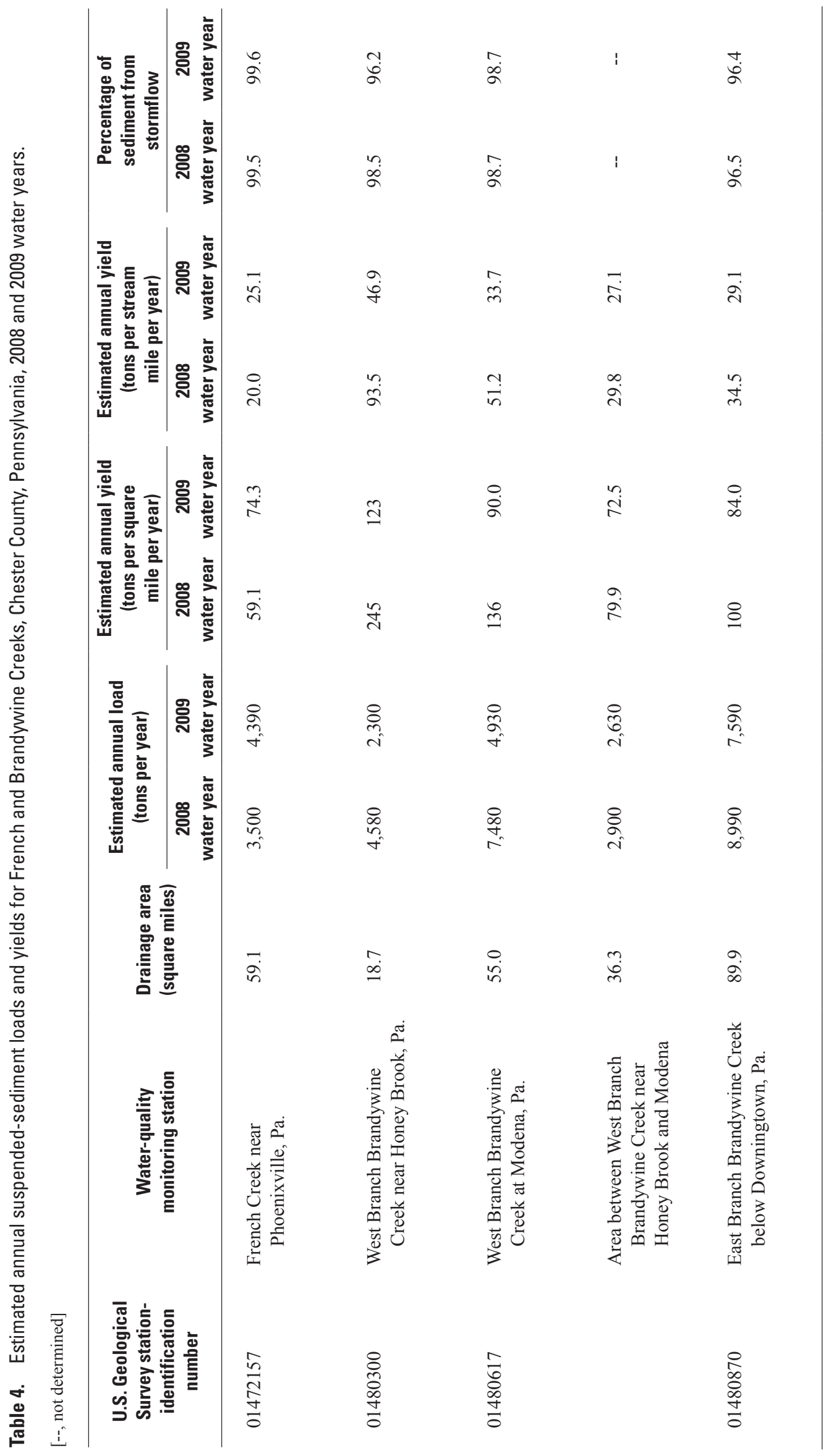



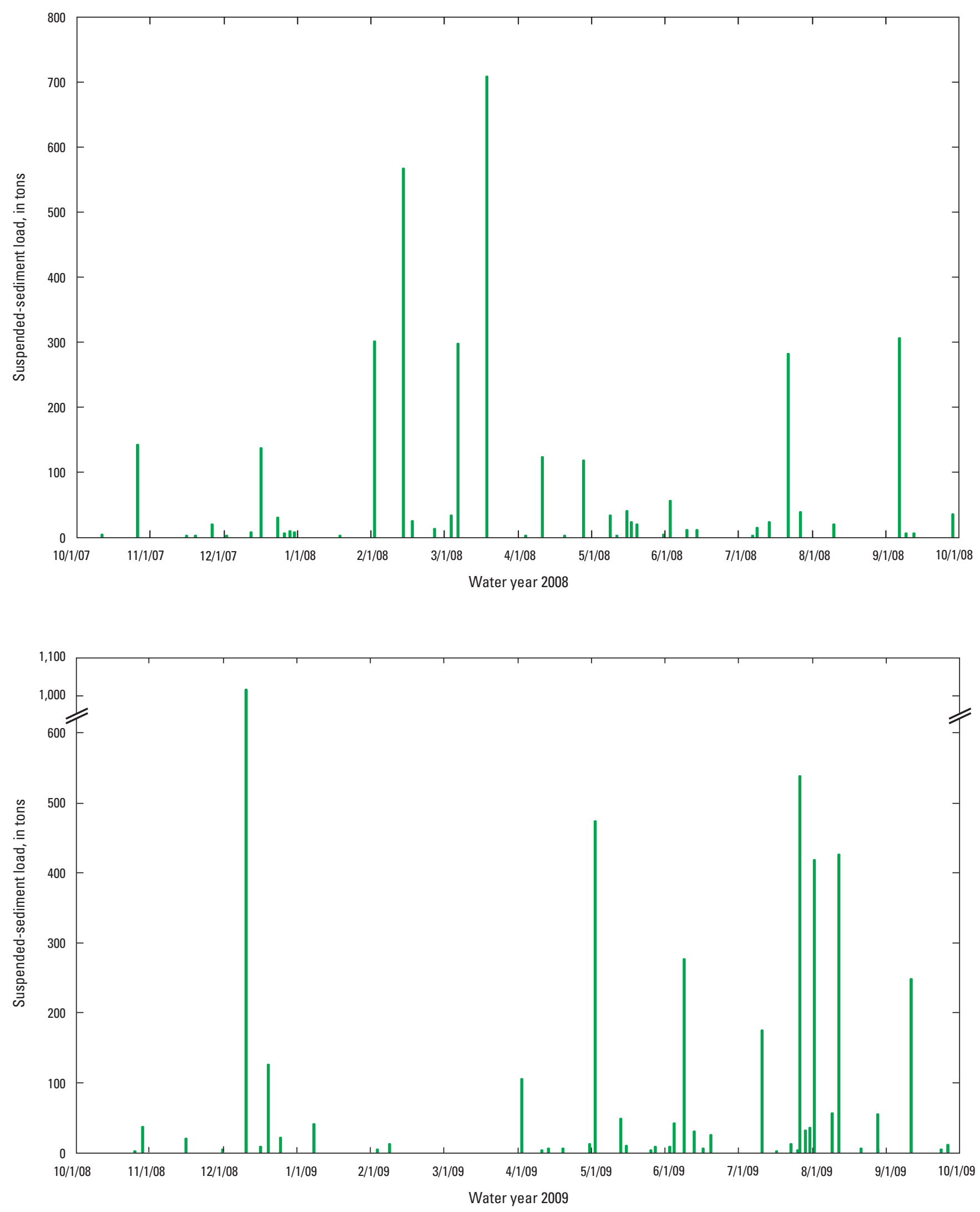

Figure 9. Suspended-sediment loads for storms at French Creek near Phoenixville, Pennsylvania, 2008 and 2009 water years. 


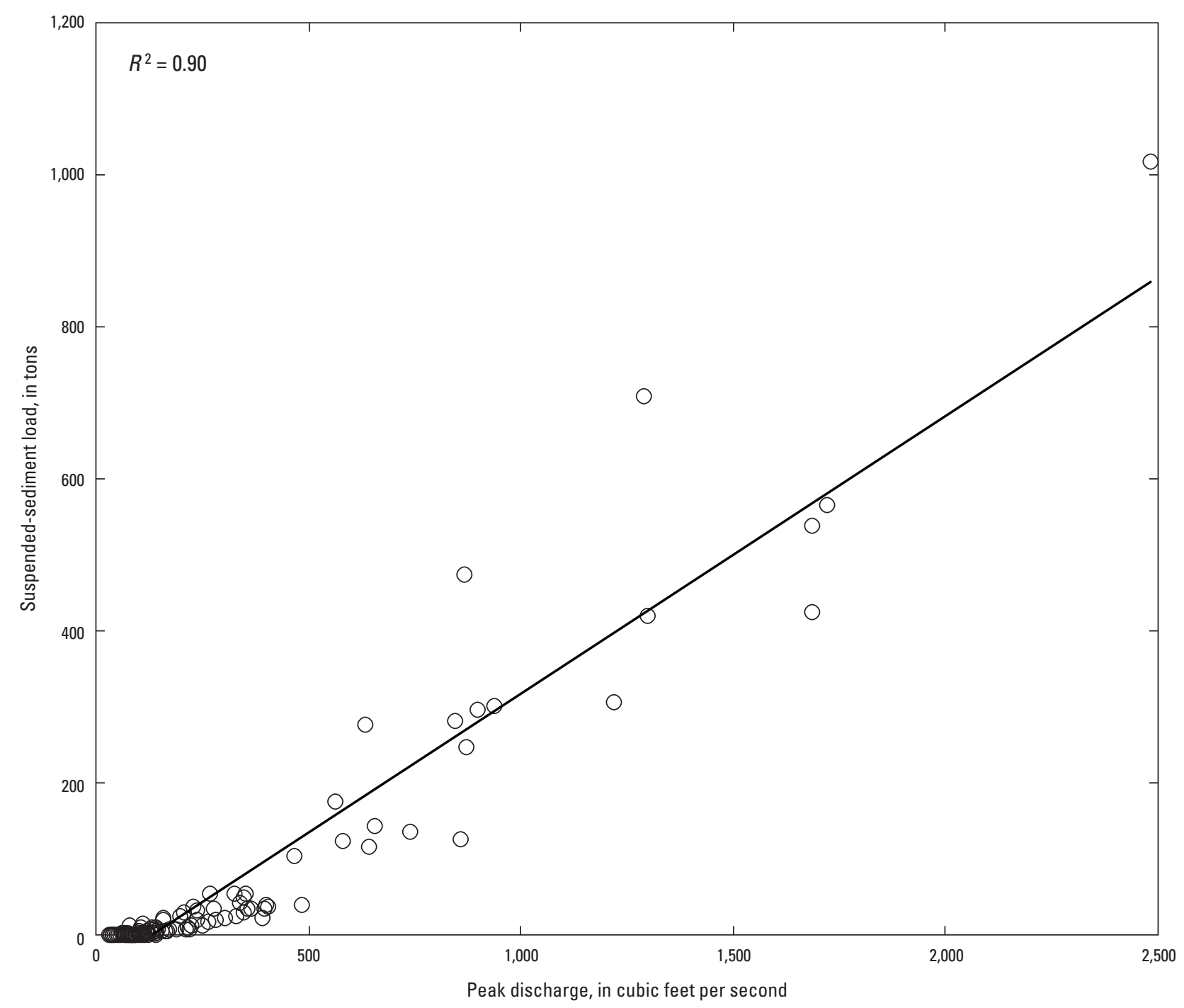

Figure 10. Relation of storm suspended-sediment load to peak discharge at French Creek near Phoenixville, Pennsylvania, 2008 and 2009 water years.

March 19, February 1, February 13, and July 27, 2008, in order of load) provided 61.6 percent of the annual SSL. Storms provided 98.5 percent of the annual $S S L ; 18$ of 42 storms that produced more than 1 ton of sediment provided 90.3 percent of the annual SSL. The highest cumulative SSLs for the 2008 water year occurred during the late winter in February and March (fig. 11, table 7). For the 2009 water year, the estimated annual SSL was 2,300 tons, and the estimated yields were $123 \mathrm{ton} / \mathrm{mi}^{2}$ and 46.9 tons per stream mile (table 4 ). The storm beginning December 10, 2008, provided 17.1 percent of the annual SSL. The four storms yielding the greatest SSL (storms beginning on December 10, 2008, and August 2, June 13, and April 3, 2009, in order of load) provided 43.6 percent of the annual SSL. Storms provided 96.2 percent of the annual SSL; 24 of 44 storms that produced more than 1 ton of sediment provided 90.5 percent of the annual SSL. The highest cumulative $S S L$ for the 2009 water year occurred during December and August (fig. 11, table 8). Storm flows with the highest peak discharges generally carried the highest $\operatorname{SSLs}\left(R^{2}=0.75\right)$ (fig. 12). 


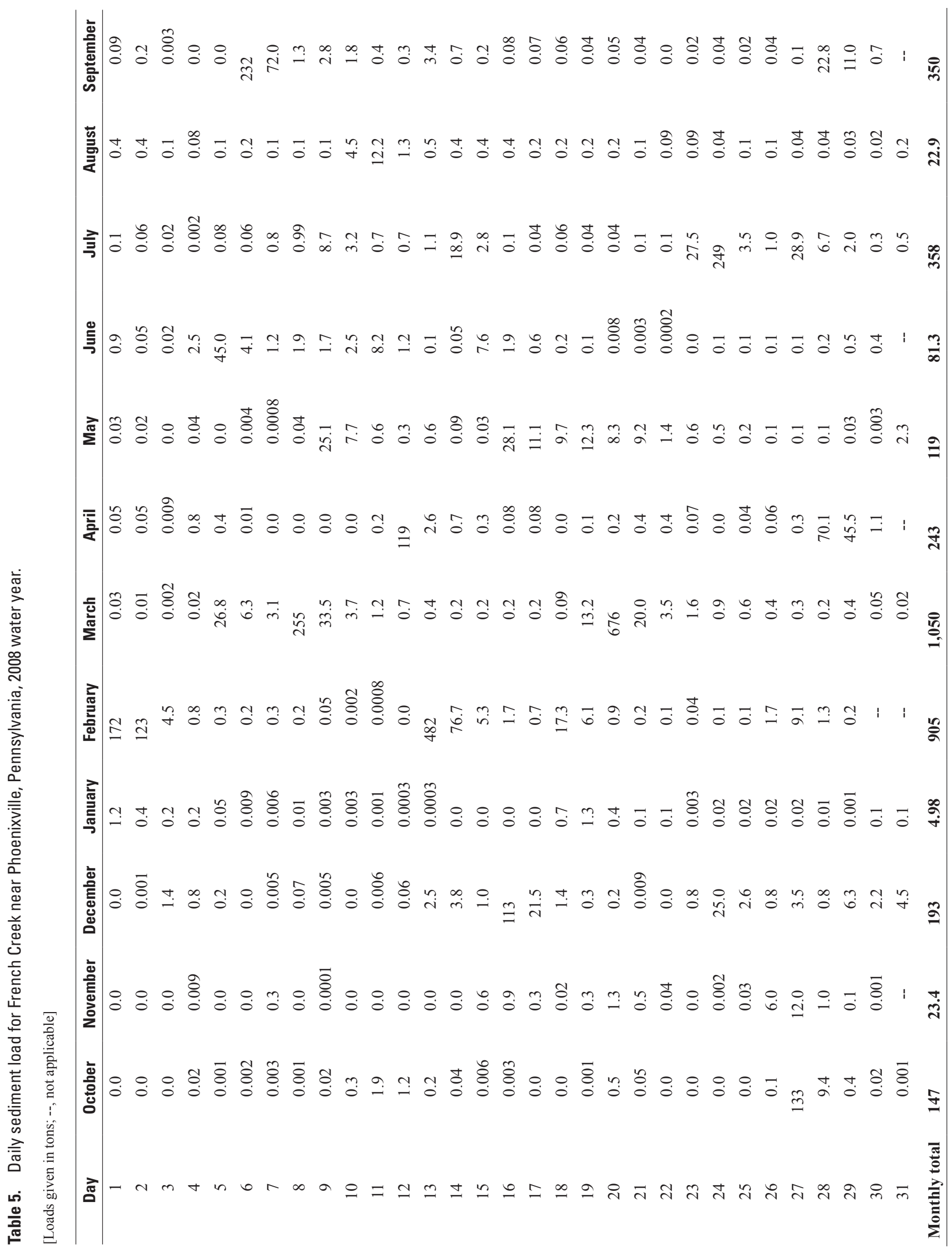




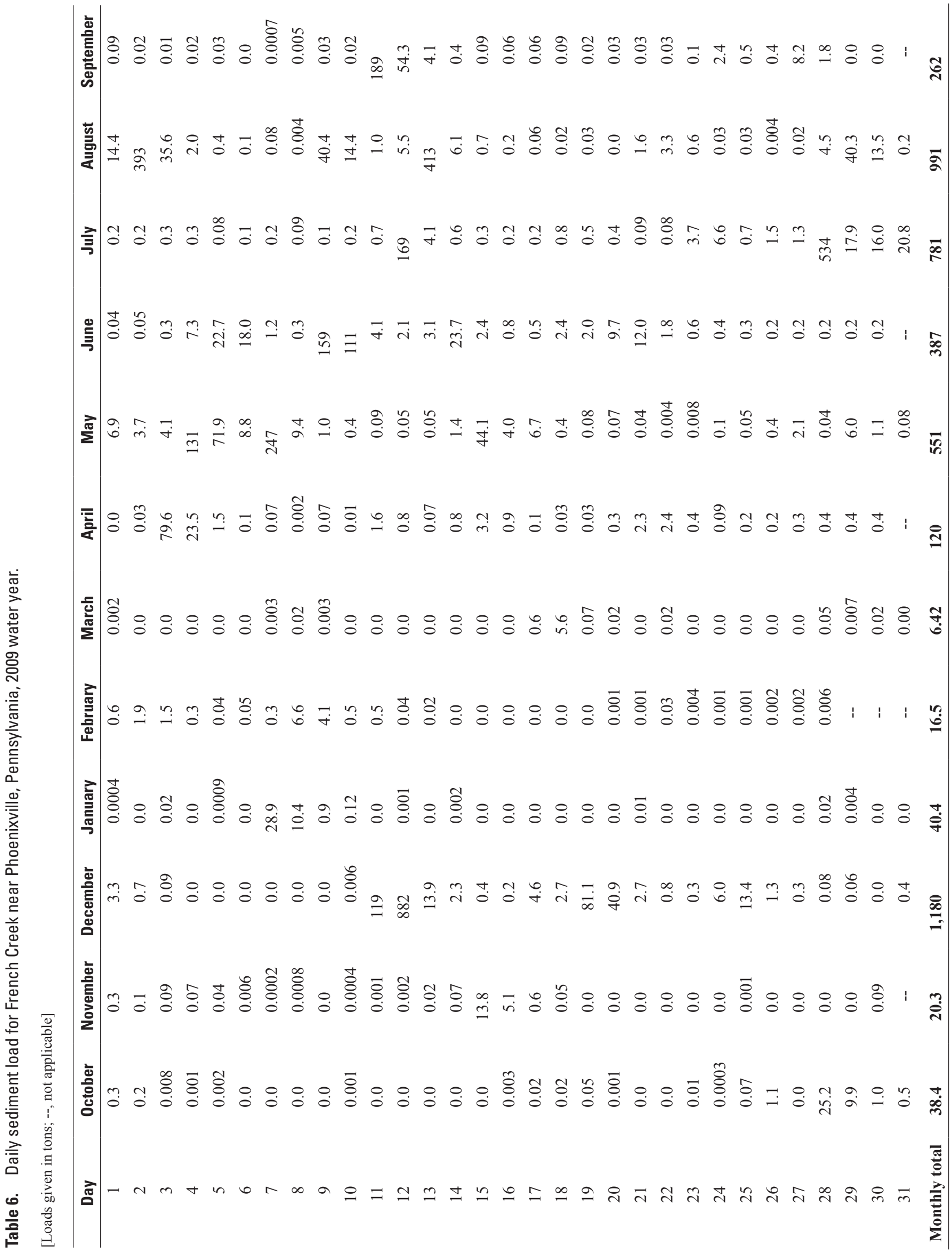



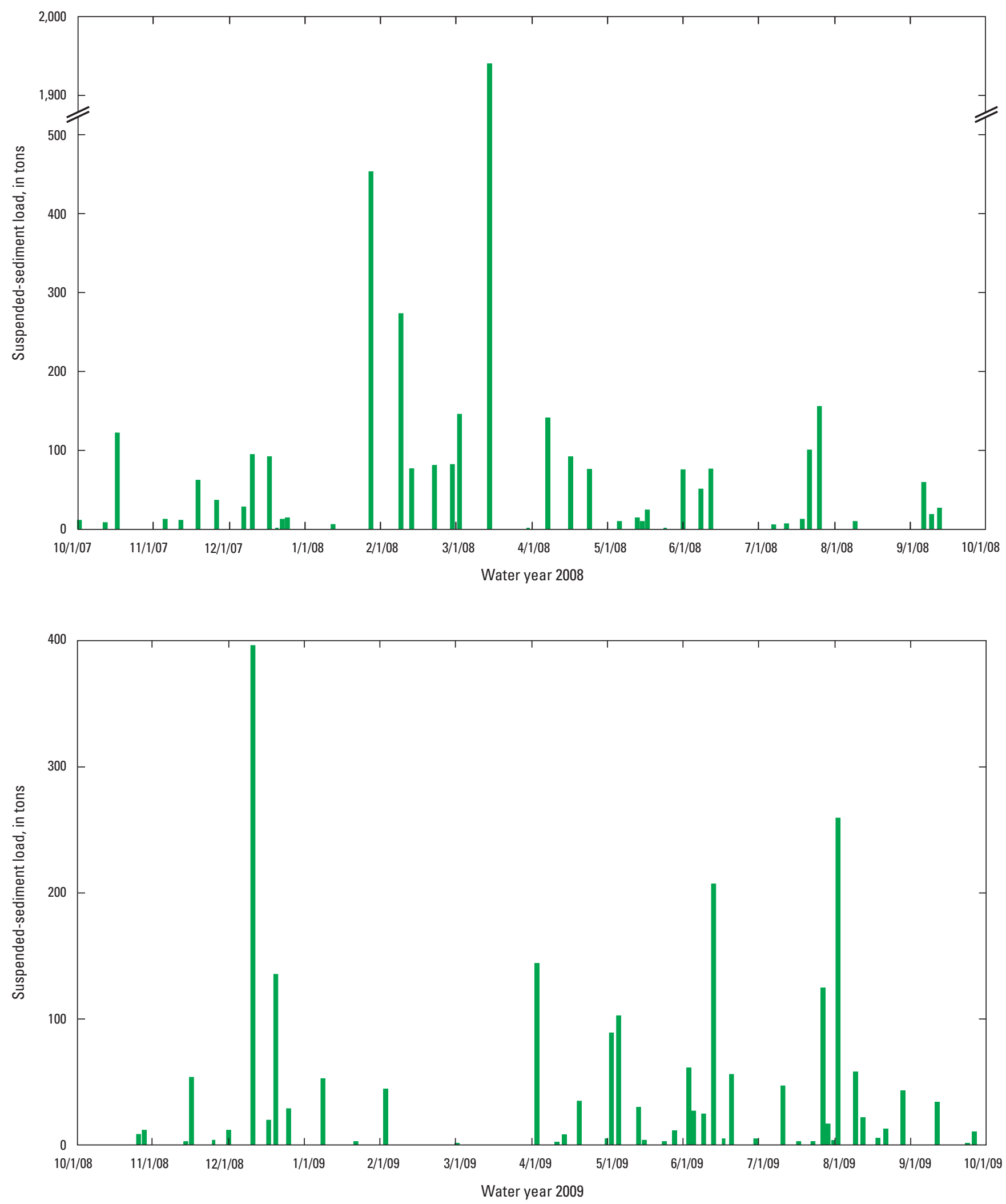

Figure 11. Suspended-sediment loads for storms at West Branch Brandywine Creek near Honey Brook, Pennsylvania, 2008 and 2009 water years. 


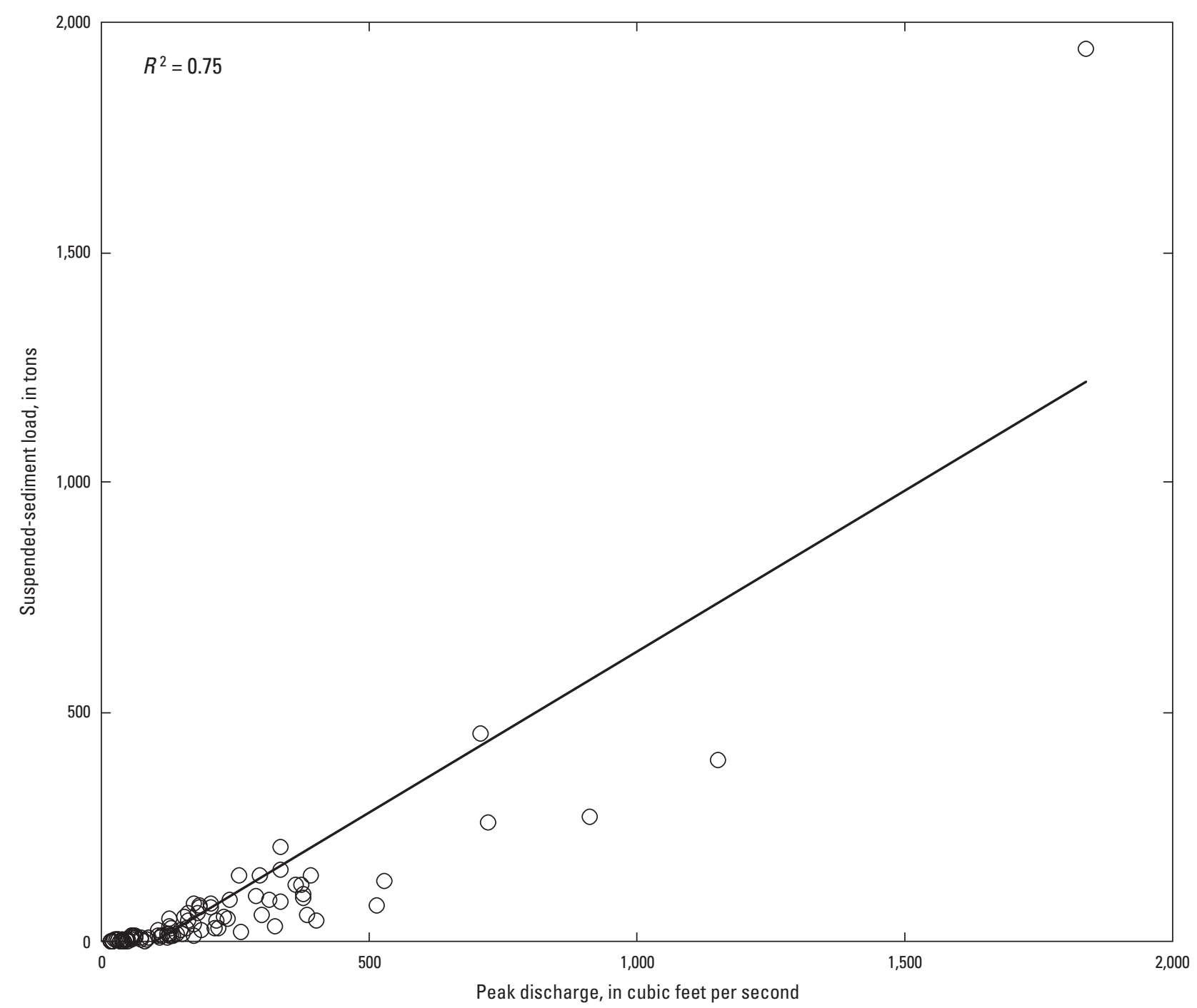

Figure 12. Relation of storm suspended-sediment load to peak discharge at West Branch Brandywine Creek near Honey Brook, Pennsylvania, 2008 and 2009 water years.

For West Branch Brandywine Creek at Modena, the estimated annual $S S L$ was 7,480 tons, and the estimated yields were $136 \mathrm{ton} / \mathrm{mi}^{2}$ and 51.2 tons per stream mile for the 2008 water year (table 4). The storm beginning March 19, 2008, provided 25.5 percent of the annual SSL. The four storms yielding the greatest SSL (storms beginning on March 19, March 7, February 1, and February 13, 2008, in order of load) provided 65.6 percent of the annual SSL. Storms provided 99.3 percent of the annual $S S L ; 12$ of 45 storms that produced more than 1 ton of sediment provided 90.3 percent of the annual SSL. The highest cumulative SSLs for the 2008 water year occurred during the late winter in February and March (fig. 13, table 9). For the 2009 water year, the estimated annual SSL was 4,930 tons, and the estimated yields were $90 \mathrm{ton} / \mathrm{mi}^{2}$ and 33.7 tons per stream mile (table 4 ). The storm beginning December 10, 2008, provided 27.5 percent of the annual SSL. The four storms yielding the greatest SSL (storms beginning on December 10, 2008, and August 2, June 11, and August 9, 2009, in order of load) provided 50.8 percent of the annual SSL. Storms provided 98.7 percent of the annual SSL; 17 of 39 storms that produced more than 1 ton of sediment provided 90.4 percent of the annual SSL. The highest cumulative SSLs for the 2009 water year occurred during December and August (fig. 13, table 10). Storm flows with the highest peak discharge generally carried the highest $\operatorname{SSL}\left(R^{2}=0.67\right)$ (fig. 14). 


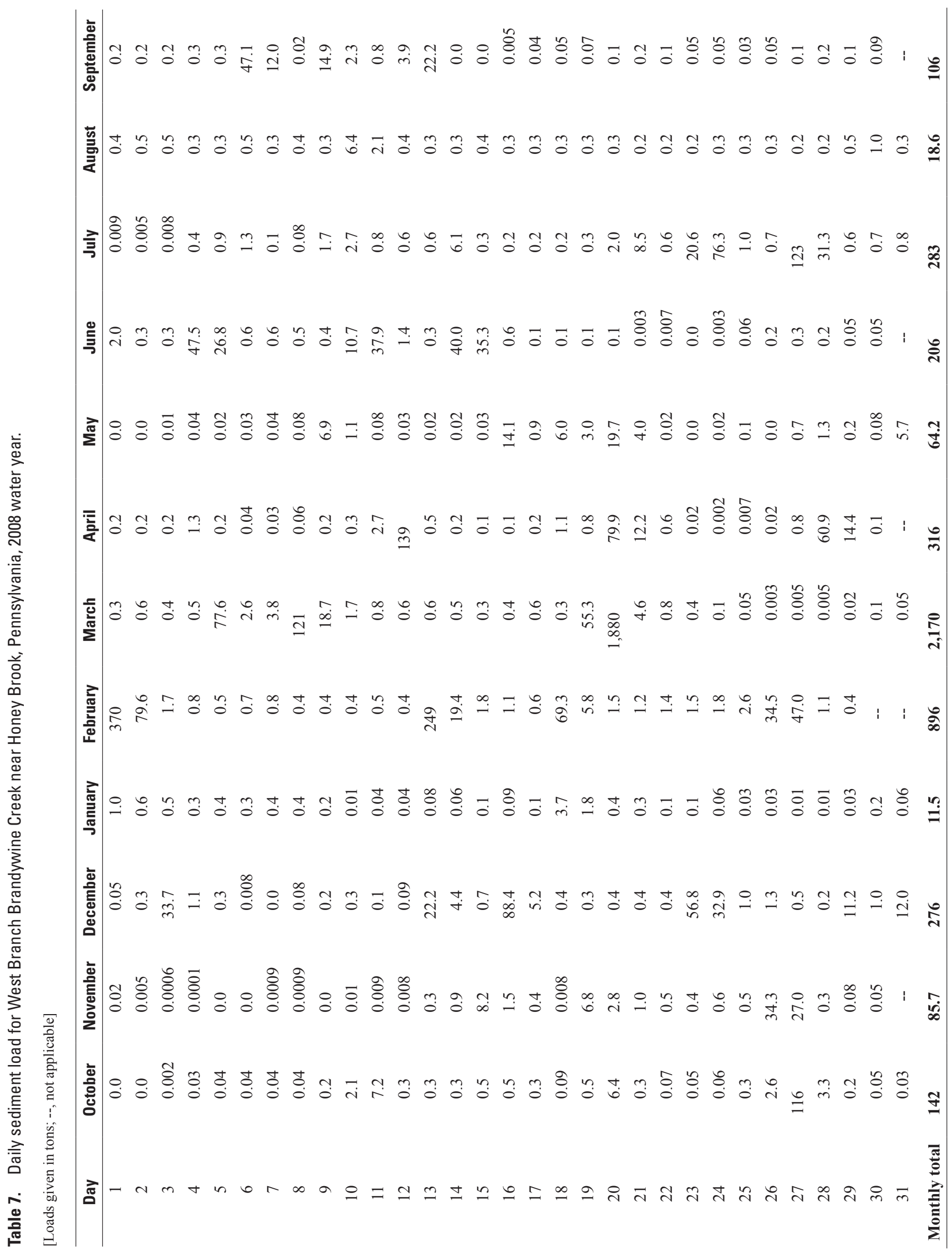




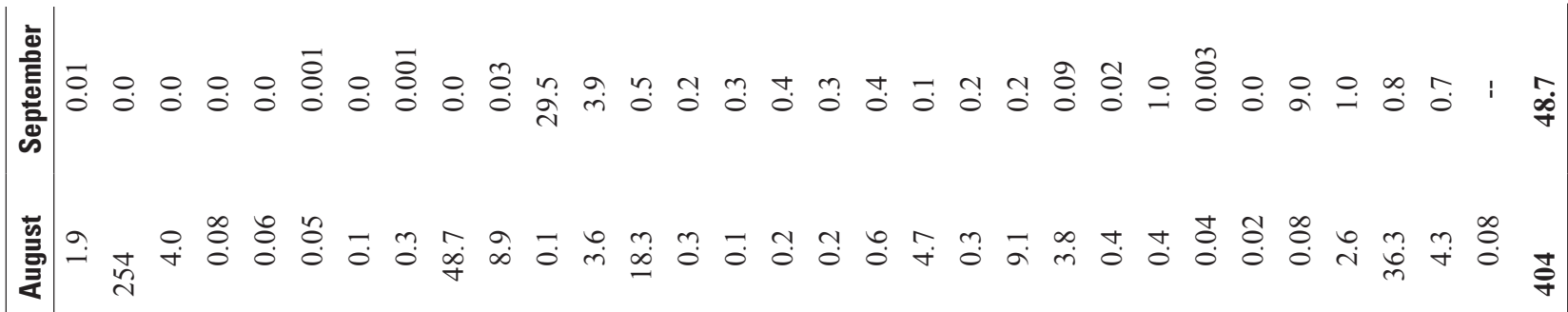

$$
\begin{aligned}
& \text { ఫ) }
\end{aligned}
$$

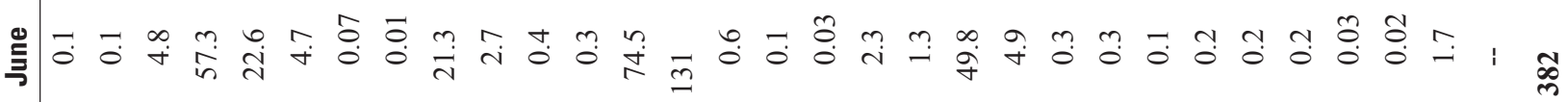

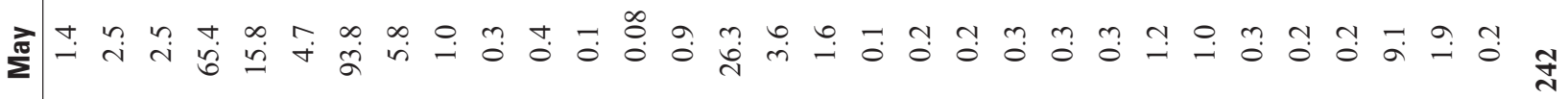

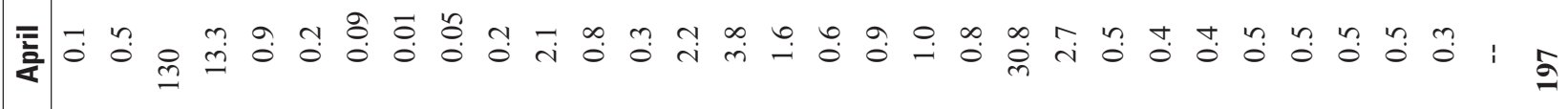

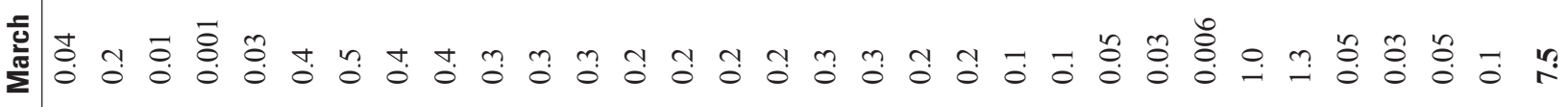

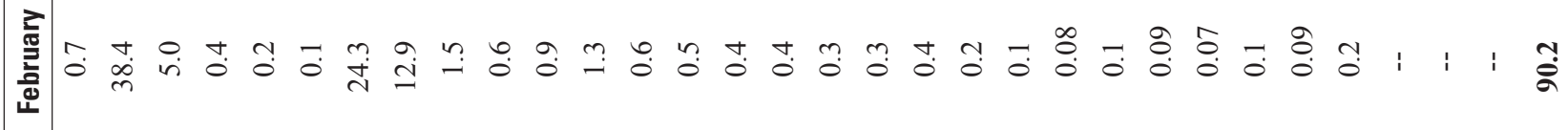

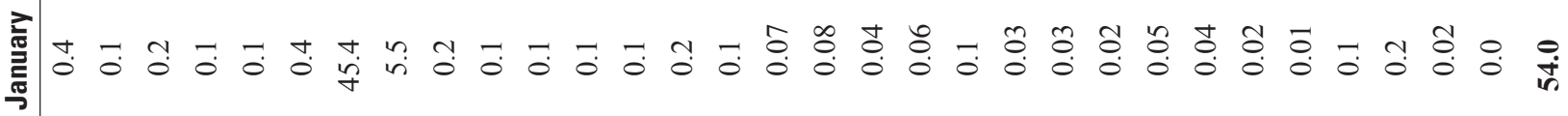

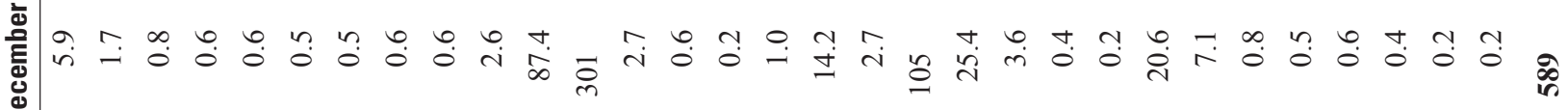

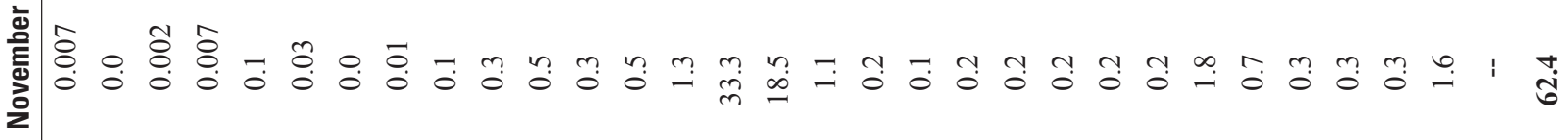

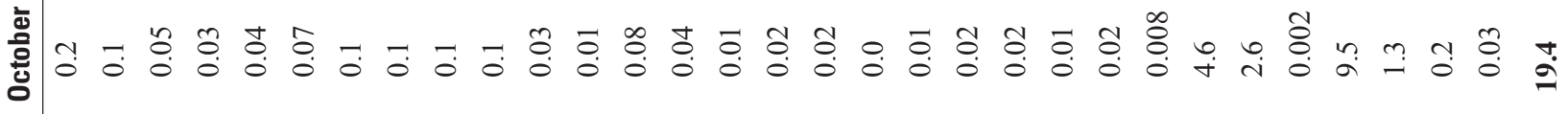

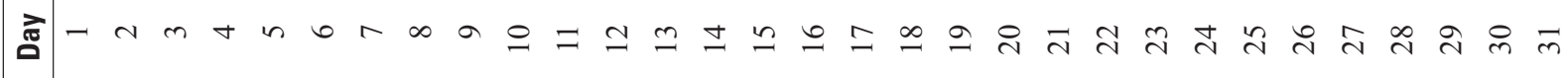



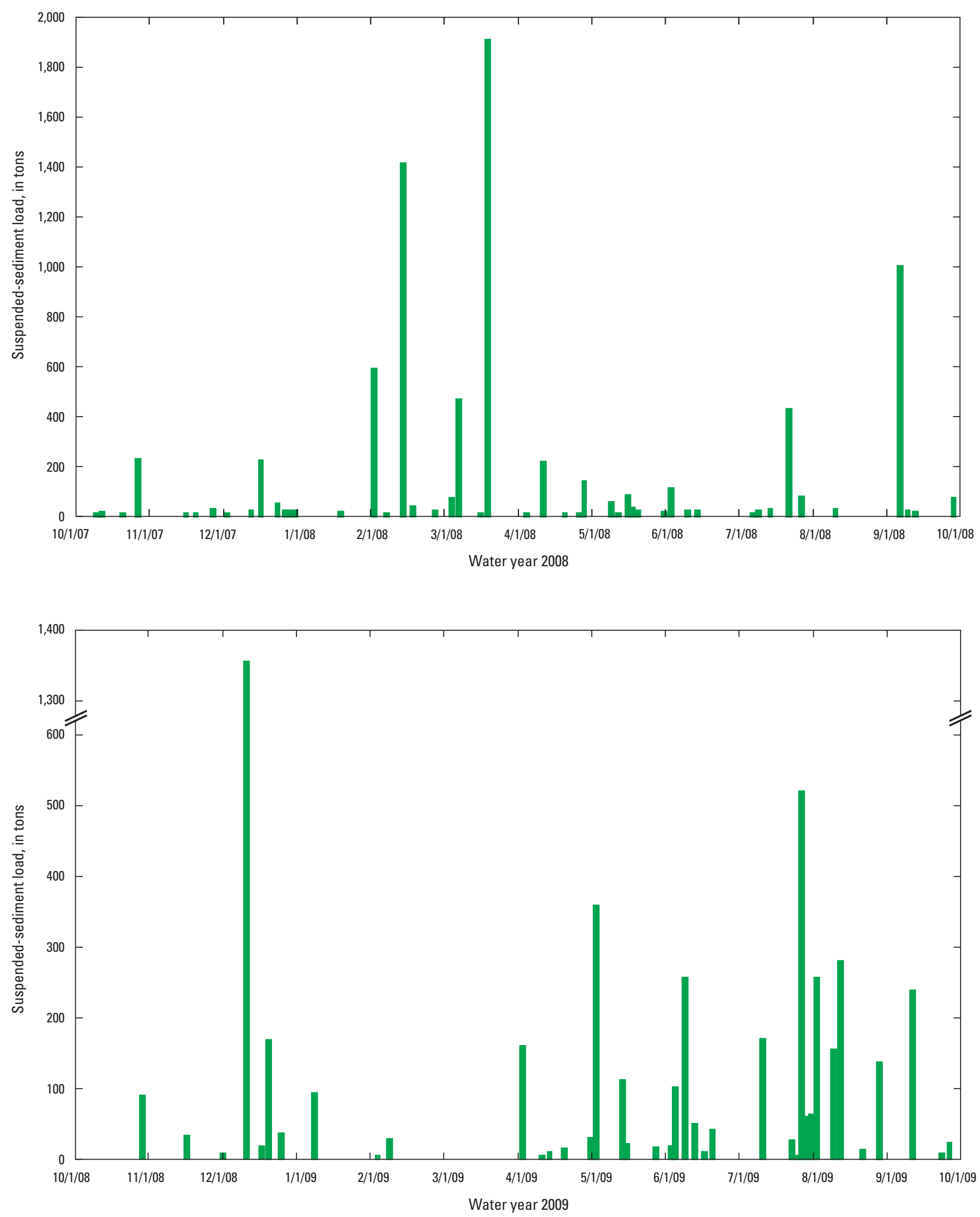

Figure 13. Suspended-sediment loads for storms at West Branch Brandywine Creek at Modena, Pennsylvania, 2008 and 2009 water years. 


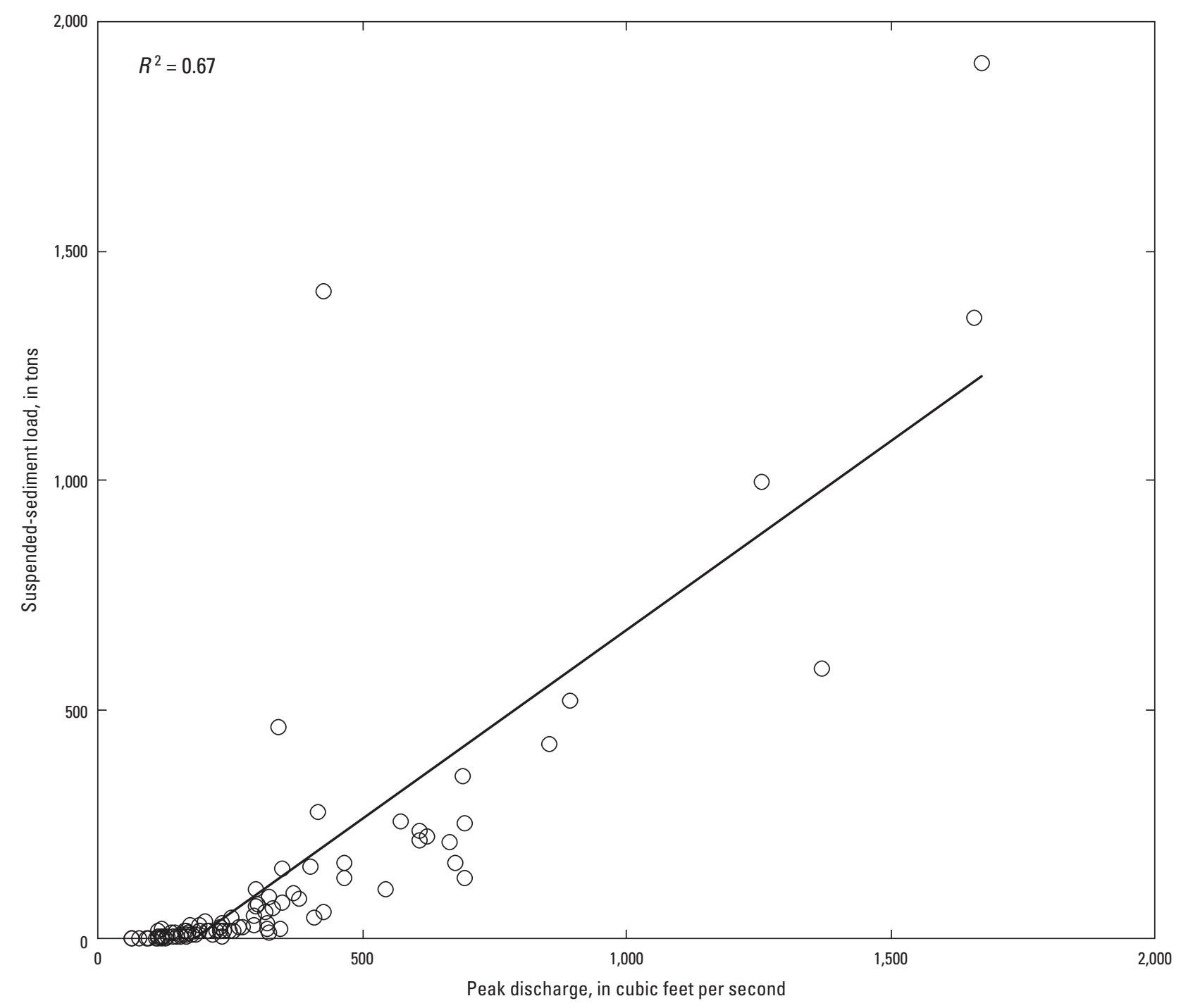

Figure 14. Relation of storm suspended-sediment load to peak discharge at West Branch Brandywine Creek at Modena, Pennsylvania, 2008 and 2009 water years.

For the drainage area between stations West Branch Brandywine Creek near Honey Brook and West Branch Brandywine Creek at Modena (drainage area of $36.6 \mathrm{mi}^{2}$ ), the estimated annual $S S L$ was 2,900 tons, and the estimated yields were $79.9 \mathrm{ton} / \mathrm{mi}^{2}$ and 29.8 tons per stream mile for the 2008 water year. For the 2009 water year, the estimated annual SSL was 2,630 tons, and the estimated yields were $72.5 \mathrm{ton} / \mathrm{mi}^{2}$ and 27.1 tons per stream mile (table 4).

For East Branch Brandywine Creek below Downingtown, the estimated annual SSL was 8,990 tons, and the estimated yields were 100 ton $/ \mathrm{mi}^{2}$ and 34.5 tons per stream mile for the 2008 water year (table 4). The storm beginning February 13,2008 , provided 13.4 percent of the annual SSL. The four storms yielding the greatest $S S L$ (storms beginning on February 13, February 1, March 19, and July 23, 2008, in order of load) provided 48 percent of the annual SSL. Storms provided 96.5 percent of the annual SSL; 19 of 51 storms that produced more than 1 ton of sediment provided 90.2 percent of the annual SSL. The highest cumulative SSLs for the 2008 water year occurred during late winter in February and March (fig. 15, table 11). For the 2009 water year, the estimated annual $S S L$ was 7,590 tons, and the estimated yields were $84 \mathrm{ton} / \mathrm{mi}^{2}$ and 29.1 tons per stream mile (table 4 ). The storm beginning December 11, 2008, provided 14.5 percent of the annual SSL. The four storms yielding the greatest SSL (storms beginning on December 11, 2008, and August 12, August 2, and June 9, 2009, in order of load) provided 50.1 percent of the annual SSL. Storms provided 96.4 percent of the annual $S S L ; 19$ of 47 storms that produced more than 1 ton of sediment provided 90.5 percent of the annual SSL. The highest cumulative SSLs for the 2009 water year occurred during December, June, and August (fig. 15, table 12). Storm flows with the highest peak discharges generally carried the highest $\operatorname{SSL}\left(R^{2}=0.75\right)$ (fig. 16). 


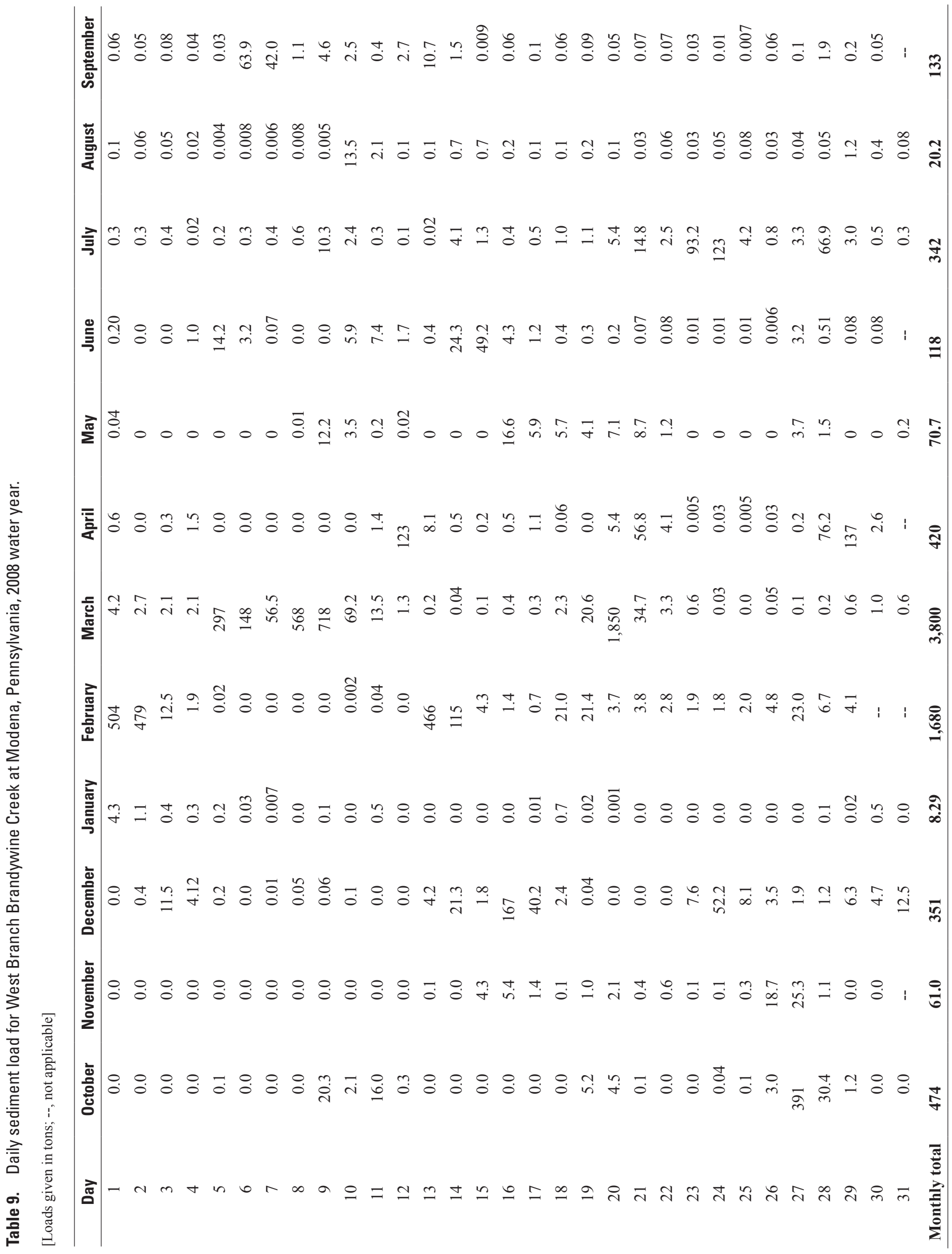




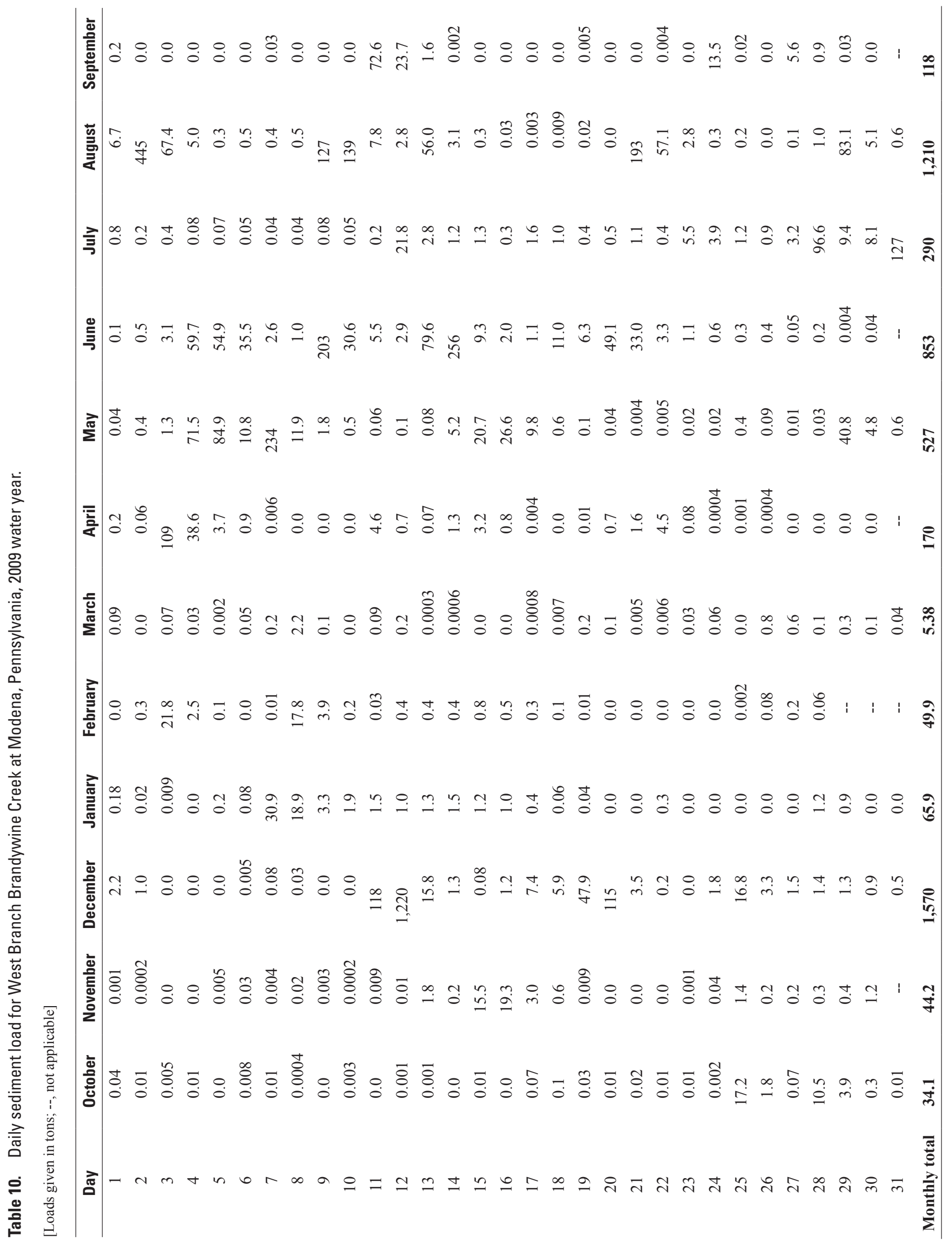



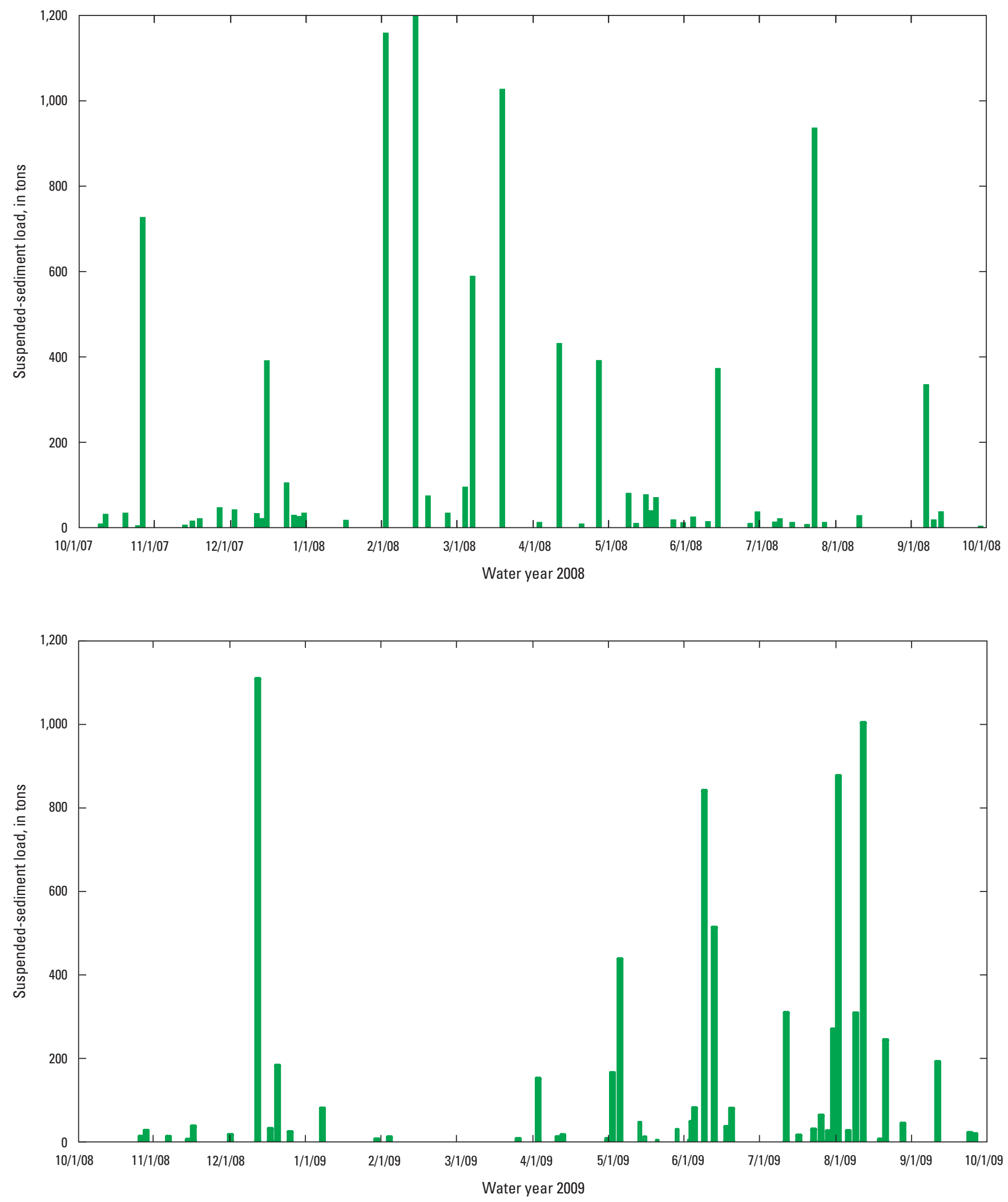

Figure 15. Suspended-sediment loads for storms at East Branch Brandywine Creek below Downingtown, Pennsylvania, 2008 and 2009 water years. 


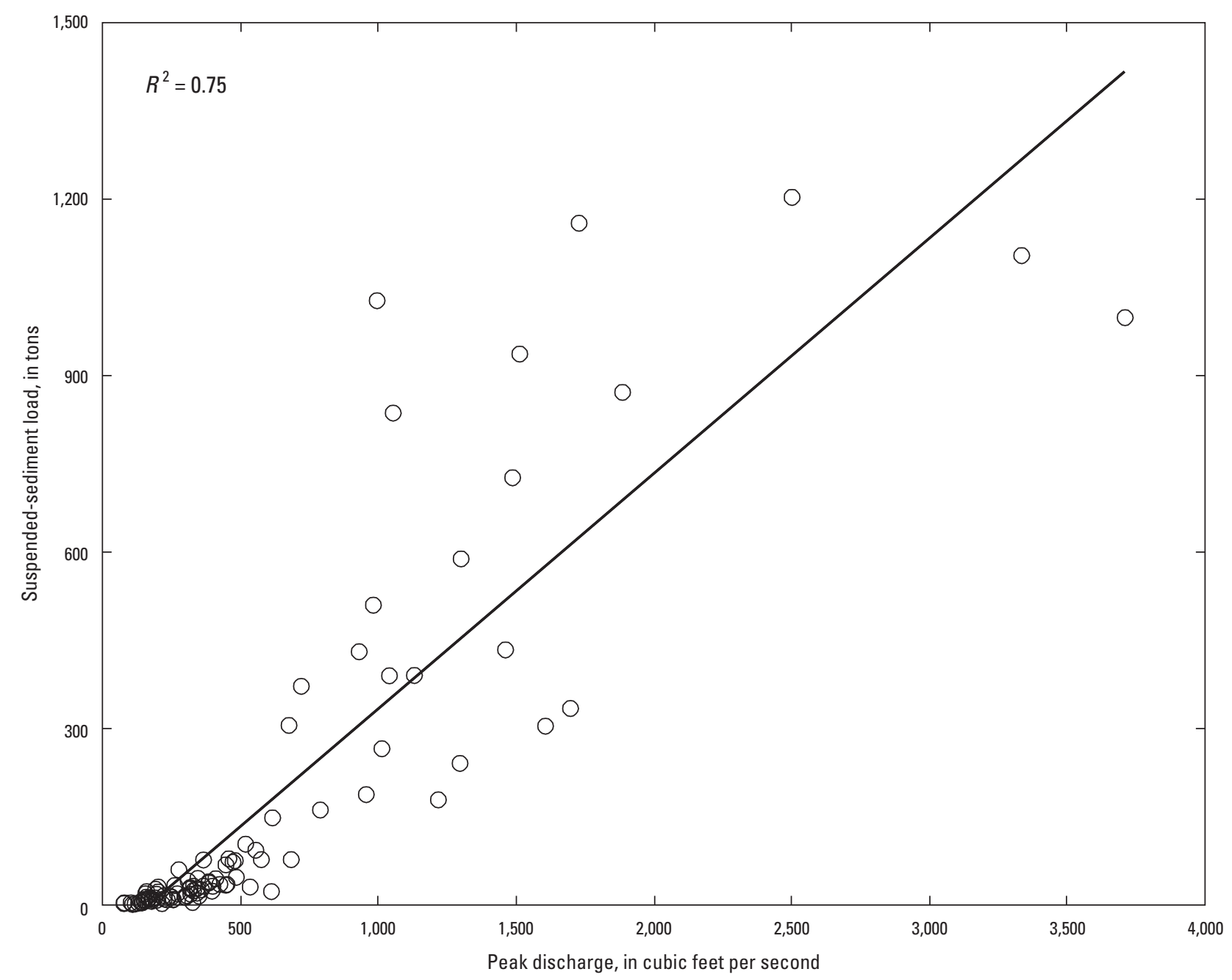

Figure 16. Relation of storm suspended-sediment load to peak discharge at East Branch Brandywine Creek below Downingtown, Pennsylvania, 2008 and 2009 water years.

For the 2008 and 2009 water years, East Branch Brandywine Creek below Downingtown had the highest estimated annual SSL, whereas West Branch Brandywine Creek near Honey Brook had the highest estimated annual suspendedsediment yield (table 4). West Branch Brandywine Creek at Modena had the second highest estimated annual suspendedsediment yield. The high suspended-sediment yield, in part, may be the result of the relatively high SSL contributed by the upstream Honey Brook subbasin. For the 2008 and 2009 water years, French Creek near Phoenixville had the lowest suspended-sediment yields. For the 2008 water year, French Creek had the lowest annual SSL, and for the 2009 water year, West Branch Brandywine Creek near Honey Brook had the lowest annual SSL.

For all four basins, storms provided more than 96 percent of the annual SSL. Generally, in each basin four storms provided over half the annual SSL each year. The SSLs in 2008, in general, were highest in the winter months of February and March, whereas in 2009, SSLs were highest in December and August. 


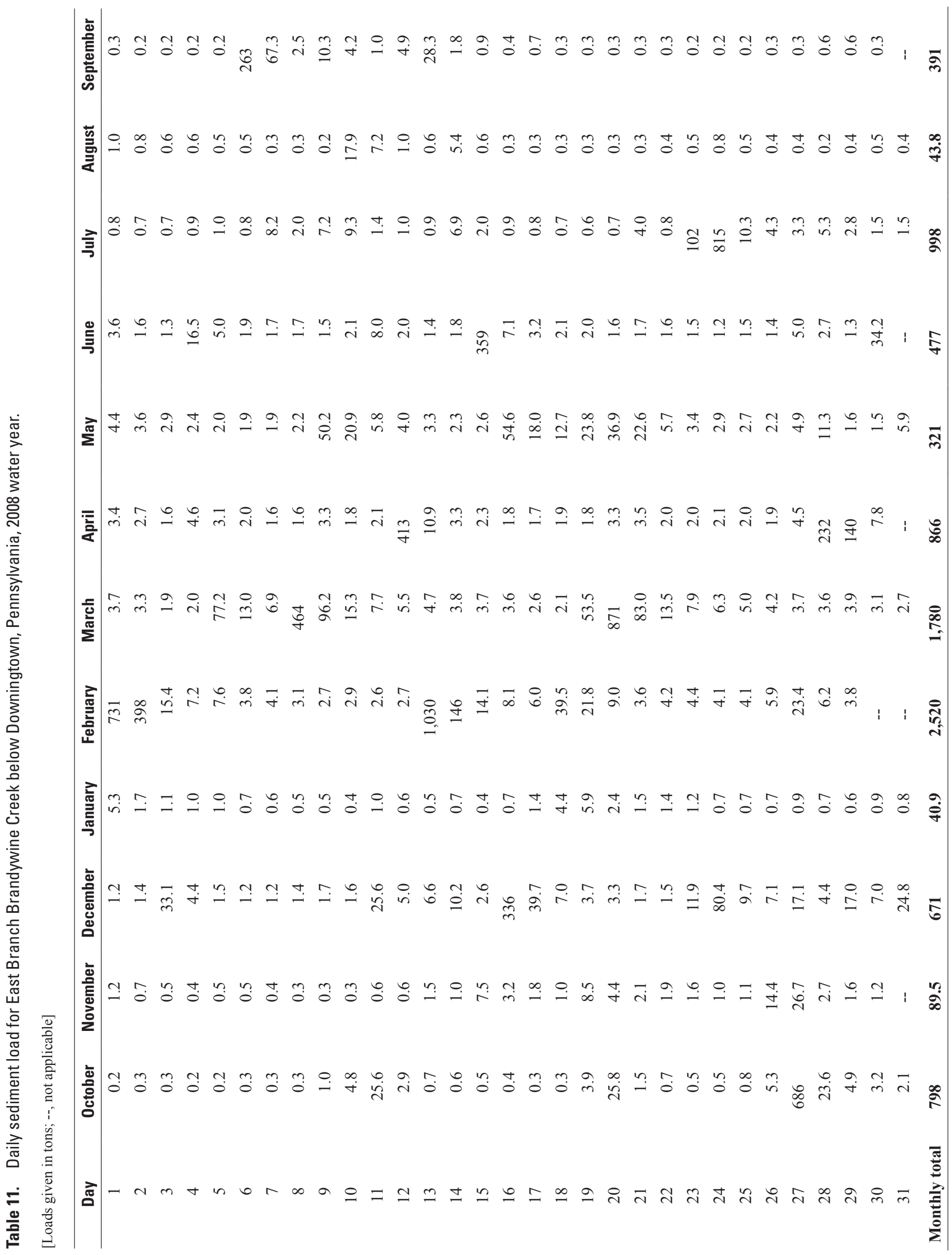




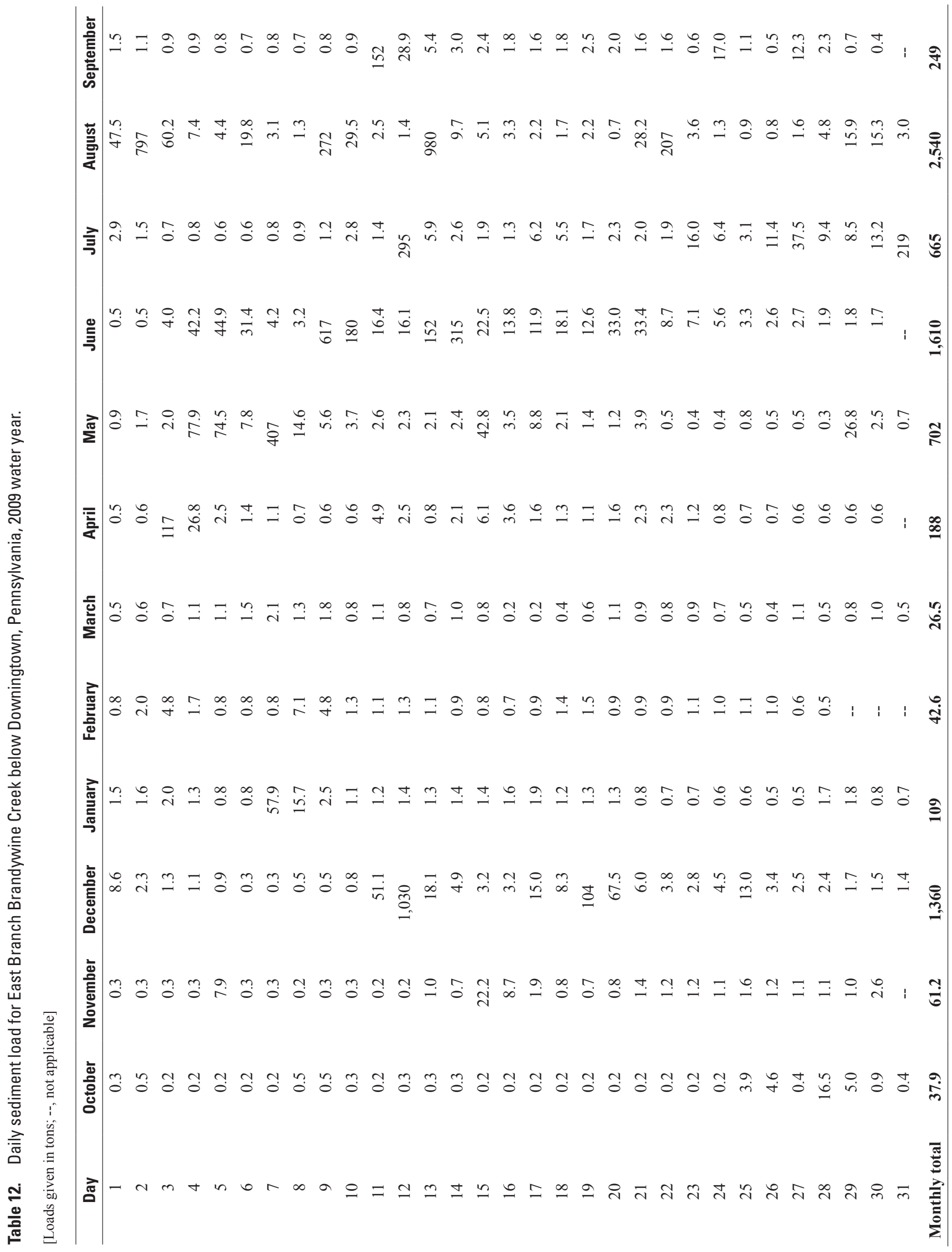




\section{Limitations of the Investigation}

Although the use of turbidity data to estimate SSC provides better estimates than the traditional discharge-based approach, the method is not without limitations. The limitations range from data-collection challenges to limitations in data analysis. Consideration must be given to site-specific conditions to ensure the turbidity sensors are adequately protected from high water, high velocities, and any associated debris, while maintaining acceptable in-stream performance. Optical turbidity sensors are susceptible to fouling by biological growth, siltation, and entangled debris. Turbidity sensors need to be calibrated frequently to prevent equipment drift, and equipment fouling can result in the loss of data. Turbidity values for periods of lost record were estimated.

The relations of SSC to turbidity described in this report are site specific and may be applicable only to the 2008-09 water years. Differences in basin and land-use characteristics produce different SSC to turbidity relations, and, therefore, the relations are different for each station. The regression equations describe the $S S C$ to turbidity relations for water years 2008-09. Additional SSC and turbidity data collected for a particular station may change the relations.

\section{Summary and Conclusions}

In-stream continuous turbidity, which was used as a surrogate for $S S C$, and discharge data, in conjunction with measured SSC data, were used to compute a time-series of $S S C$ and $S S L$ at four stream stations in Chester County, Pa. Turbidity and SSC data were collected by the USGS at the four stream stations in cooperation with the Chester County Water Resources Authority and the Chester County Health Department with the intent of developing time-series SSC estimates. Turbidity and SSC data were collected at French Creek near Phoenixville, West Branch Brandywine Creek near Honey Brook, West Branch Brandywine Creek at Modena, and East Branch Brandywine Creek below Downingtown. Data collection began in April 2007.

Turbidity sensors were deployed at the four stations, and data were recorded at 15- or 30-minute intervals by a data logger and uploaded every 1 to 4 hours to the USGS database. Data from the in-situ sensors were compared with annual cross-sectional data to verify that the in-situ sensors were installed in representative locations in the stream. No bias was noted for any of the stations. Missing data occurred because of spikes, servicing of the sensor, or fouling. If field measured values were available, they were used to replace missing data. When the period of time between missing values was small, interpolation between measured data points was used to estimate missing values. When there were large gaps in the record, data from nearby turbidity sensors and discharge and rainfall data were used to estimate missing values.
Most of the suspended-sediment samples were collected using automated samplers. Of the 24 samples collected for a storm, 1 to 6 samples were selected for laboratory analysis. These selections were made to minimize potential bias from serial correlation and reduce the effect of any one event on the overall relation between turbidity and SSC.

Regression models were developed between $S S C$ and turbidity $(T)$ for each station using SSC sample data collected from the automated samplers and turbidity data collected at each station. Six regression models were initially developed for each station: (1) $S S C$ in relation to $T$, (2) $S S C$ to $Q$, (3) $S S C$ to $T$ and $Q$, (4) $\log _{10} S S C$ to $\log _{10} T$, (5) $\log _{10} S S C$ to $\log _{10} Q$, and (6) $\log _{10} S S C$ to $\log _{10} T$ and $\log _{10} Q$. Statistics, including coefficient of determination $\left(R^{2}\right)$, adjusted $R^{2}$, standard error, prediction error sum of squares, Mallow's $C p$, variance inflation factor, probability plot correlation coefficient, and model standard percentage error, were used to evaluate the models. Uncertainty of regression estimates were determined by 90-percent prediction intervals.

Instantaneous $S S L$ was computed from time-series turbidity and discharge data for the 2008 and 2009 water years using the regression equations developed for each station. The instantaneous computations of $S S L$ were summed to provide daily, storm, and annual loads. The annual SSL contributed from each subbasin was divided by the upstream drainage area to estimate the annual sediment yield.

Storms provided more than 96 percent of the annual SSL for all four basins. In each basin, four storms generally provided more than one-half the annual SSL each year. Storm flows with the highest peak discharges generally carried the highest SSLs. For all stations the greatest SSL occurred during the late winter in February and March during the 2008 water year. During the 2009 water year, the greatest SSL occurred during December and August.

For French Creek near Phoenixville, a linear regression model using turbidity as the explanatory variable was selected. Turbidity explained 96 percent of the variability in $S S C$ values. The estimated annual $S S L$ was 3,500 tons, and the estimated yields were $59.1 \mathrm{ton} / \mathrm{mi}^{2}$ and 20 tons per stream mile for the 2008 water year. The storm beginning March 19, 2008, provided 20.4 percent of the annual SSL. The four storms that yielded the greatest $S S L$ s provided 54 percent of the annual SSL. For the 2009 water year, the estimated annual SSL was 4,390 tons, and the estimated yields were $74.3 \mathrm{ton} / \mathrm{mi}^{2}$ and 25.1 tons per stream mile. The storm beginning December 10, 2008, provided 23.2 percent of the annual SSL. The four storms that yielded the greatest SSLs provided 56.1 percent of the annual SSL.

For West Branch Brandywine Creek near Honey Brook, the correlations among $S S C, T$, and discharge were lower than for the other stations. A linear regression model using turbidity as the explanatory variable was selected. Turbidity explained 74 percent of the variability in $S S C$ values. The estimated annual $S S L$ was 4,580 tons, and the estimated yields were $245 \mathrm{ton} / \mathrm{mi}^{2}$ and 93.5 tons per stream mile for the 2008 water 
year. The storm beginning March 19, 2008, provided 42.4 percent of the annual SSL. The four storms that yielded the greatest SSLs provided 61.6 percent of the annual SSL. For the 2009 water year, the estimated annual SSL was 2,300 tons, and the estimated yields were $123 \mathrm{ton} / \mathrm{mi}^{2}$ and 46.9 tons per stream mile. The storm beginning December 10, 2008, provided 17.1 percent of the annual $S S L$. The four storms that yielded the greatest $S S L$ s provided 43.6 percent of the annual SSL.

For West Branch Brandywine Creek at Modena, a linear regression model using turbidity as the explanatory variable was selected. Turbidity explained 94 percent of the variability in $S S C$ values. The estimated annual SSL was 7,480 tons, and the estimated yields were $136 \mathrm{ton} / \mathrm{mi}^{2}$ and 51.2 tons per stream mile for the 2008 water year. The storm beginning March 19, 2008 , provided 25.5 percent of the annual SSL. The four storms that yielded the greatest SSLs provided 65.6 percent of the annual SSL. For the 2009 water year, the estimated annual $S S L$ was 4,930 tons, and the estimated yields were $90 \mathrm{ton} / \mathrm{mi}^{2}$ and 33.7 tons per stream mile. The storm beginning December 10, 2008, provided 27.5 percent of the annual SSL. The four storms that yielded the greatest SSLs provided 50.8 percent of the annual SSL.

For East Branch Brandywine Creek below Downingtown, a linear regression model using a logarithmic base-10 transformation of both the response and explanatory variables was selected. Turbidity explained 94 percent of the variability in SSC values. The estimated annual SSL was 8,990 tons, and the estimated yields were $100 \mathrm{ton} / \mathrm{mi}^{2}$ and 34.5 tons per stream mile for the 2008 water year. The storm beginning February 13, 2008, provided 13.4 percent of the annual SSL. The four storms that yielded the greatest SSLs provided 48 percent of the annual SSL. For the 2009 water year, the estimated annual SSL was 7,590 tons, and the estimated yields were $84 \mathrm{ton} / \mathrm{mi}^{2}$ and 29.1 tons per stream mile. The storm beginning December 11, 2008, provided 14.5 percent of the annual $S S L$. The four storms that yielded the greatest SSLs provided 50.1 percent of the annual SSL.

For the 2008 and 2009 water years, East Branch Brandywine Creek below Downingtown had the highest estimated annual SSL, and West Branch Brandywine Creek near Honey Brook had the highest estimated annual suspended-sediment yield. West Branch Brandywine Creek at Modena had the second highest estimated annual suspended-sediment yield. The high suspended-sediment yield could be partly the result of the high SSL contributed by the upstream Honey Brook subbasin. French Creek had the lowest suspended-sediment yields for the 2008 and 2009 water years. French Creek had the lowest annual SSL for the 2008 water year, and West Branch Brandywine Creek near Honey Brook had the lowest annual SSL for the 2009 water year.

\section{References Cited}

Bragg, J.M., Sobieszczyk, Steven, Uhrich, M.A., and Piatt, D.R., 2007, Suspended-sediment loads and yields in the North Santiam River Basin, Oregon, water years 1999-2004: U.S. Geological Survey Scientific Investigations Report 2007-5187, 26 p., available online at http://pubs.usgs.gov/sir/2007/5187/.

Duan, Naihua, 1983, Smearing estimate-a nonparametric retransformation method: Journal of the American Statistical Association, v. 78, no. 383, p. 605-610.

Helsel, D.R., and Hirsch, R.M., 1992, Statistical methods in water resources: New York, Elsevier, 522 p.

Helsel, D.R., and Hirsch, R.M., 2002, Statistical methods in water resources: U.S. Geological Survey Techniques of Water-Resources Investigations, chap. A3, book 4, 510 p., available online at http://pubs.usgs.gov/twri/twri4a3/.

Lee, C.J., Rasmussen, P.P., and Ziegler, A.C., 2008, Characterization of suspended-sediment loading to and from John Redmond Reservoir, east-central Kansas, 2007-2008: U.S. Geological Survey Scientific Investigations Report 2008-5123, 25 p., available online at http://pubs.usgs.gov/ sir $/ 2008 / 5123 /$.

Pennsylvania Department of Environmental Protection, 2010, 2010 Pennsylvania integrated water quality monitoring and assessment report clean water act section 305(b) report and 303(d) list: 67 p.

Rasmussen, P.P., Gray, J.R., Glysson, G.D., and Ziegler, A.C., 2009, Guidelines and procedures for computing time-series suspended-sediment concentrations and loads from instream turbidity-sensor and streamflow data: U.S. Geological Survey Techniques and Methods, book 3, chap. C4, 54 p., available online at http://pubs.usgs.gov/tm/tm3c4/.

Senior, L.A., and Koerkle, E.H., 2003, Simulation of streamflow and water quality in the Brandywine Creek subbasin of the Christina River Basin, Pennsylvania and Delaware, 1994-98: U.S. Geological Survey Water-Resources Investigations Report 2002-4279, 207 p., available online at http://pa.water.usgs.gov/reports/wrir02-4279.pdf.

U.S. Environmental Protection Agency, 1999, Guidance manual for compliance with the interim enhanced surface water treatment rule: EPA-815-R-99-010, variously paginated. 
Wagner, R.J., Boulger, R.W., Jr., Oblinger, C.J., and Smith, B.A., 2006, Guidelines and standard procedures for continuous water-quality monitors-Station operation, record computation, and data reporting: U.S. Geological Survey Techniques and Methods 1-D3, 51 p. +8 attachments; accessed July 6, 2011, at http://pubs.water.usgs.gov/tm 1d3.

Wilde, F.D., Radtke, D.B., Gibs, J., and Iwatsubo, R.T., eds., 1999, Collection of water samples, in National field manual for the collection of water-quality data: U.S. Geological Survey Techniques of Water-Resources Investigations, book 9 , chap. A4, variously paginated, available online at http://water.usgs.gov/owq/FieldManual/. 
For more information about this publication, contact:

U.S. Geological Survey

215 Limekiln Road

New Cumberland, PA 17070

http://pa.water.usgs.gov/ 
